\title{
Theorizing American Studies : German Interventions into an Ongoing Debate
}

\author{
(2) OpenEdition \\ Journals \\ Édition électronique \\ URL : https://journals.openedition.org/ejas/470 \\ DOI : 10.4000/ejas.470 \\ ISSN : 1991-9336 \\ Éditeur \\ European Association for American Studies
}

Référence électronique

Sabine Sielke, «Theorizing American Studies: German Interventions into an Ongoing Debate», European journal of American studies [En ligne], 1-1 | 2006, document 7, mis en ligne le 12 janvier 2006, consulté le 10 juillet 2021. URL : http://journals.openedition.org/ejas/470 ; DOI : https://doi.org/ $10.4000 /$ ejas. 470

Ce document a été généré automatiquement le 10 juillet 2021.

Creative Commons License 


\section{Theorizing American Studies : German Interventions into an Ongoing Debate}

In October 1988 the (Village) Voice Literary Supplement published a four-page comic strip, drawn by S.B. Whitehead in 1986 and entitled "Great Moments in Lit-Crit" (fig. 1). This comic strip offered a history of the issues that literary critics-or rather philosophers and writers concerned with the aesthetic forms and cultural functions of literature and the arts-have busied themselves since the stone ages. ("Stone age criticism is practical," we are informed with a side kick to I.A. Richards.) Given its scope such history cannot be but reductive, even if, for me, the comic has proven to be extremely useful for teaching theory. With a twinkle in the eye its narrative traces perspectives on the relation of language and the world from the Bible-" [i]n the beginning was the word," we may read in the first image, "without the footnote"-to a certain moment in the 1980s, a moment the Voice Literary Supplement made ample fun of. The comic strip's final image, framed by (de-)construction workers employing their air hammers, visualizes the playful plurality of theoretical positions evolving in literary and cultural studies at the time as a "Lit-O-Rama," a turbulent fair that offers an array of attractions, including a "bearded lady" displayed behind bars by Michel Foucault; a shooting range where Susan Gubar, Sandra Gilbert, Mary Helen Washington, and Henry Louis Gates fire away at the established literary canon; the "wheel of history" that Raymond Williams, Terry Eagleton, and Fredric Jameson keep turning; the "tunnel d'amour" from which, all in one vehicle, Julia Kristeva, Luce Irigaray, Hélène Cixous, and Monique Wittig evolve; and a performance of the "Yale brothers" who advertise 
"four man and a theory," featuring Harold Bloom, J. Hillis Miller, Geoffrey Hartman, Paul de Man, and of course : deconstruction.

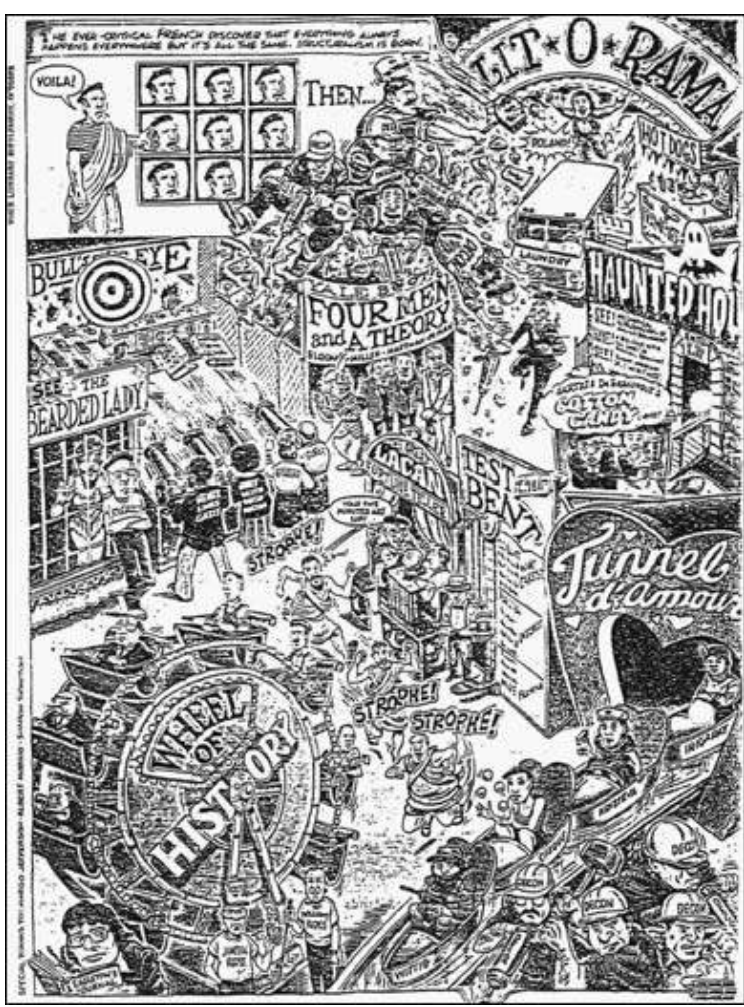

Moments in Lit-Crit," 1986

Figure 1 : S. B. Whitehead, "Great

2 I employ this obviously polemic piece here not only because its irony reminds us of how urgent a matter theory-as well as the resistance to it-became for some time, both in American and German literary and cultural studies. Meanwhile, we may perhaps agree that we all do theory all the time, even, or most particularly, if we keep insisting we do not. I also make note of this particular intervention into an ongoing debate because many of the above mentioned attractions have significantly affected the field of American Studies, evolving a centrifugal multitude of critical perspectives, thus making the 1980 s a major turning point in the process of theorizing American Studies. Or is it, I kept wondering as I worked on this essay, a 'returning point,' at least to a certain degree? Let me add that the preliminary answers I offer may be equally reductive, yet are not meant to be a comic strip (though I certainly wish I could draw).

\section{Zooming In}

3 I first envisioned this essay as a sketch of the directions the debates about methods and theoretical perspectives have taken within the field of American Studies in Germany during the last four decades. Needless to say, even a sketch of this development could easily develop into a three-volume book project. After all, if we talk about theories of American Studies in Germany we need to take into account that from the 1950s to the early 1990s German American Studies evolved in two different versions. Considering these two versions the question is not merely whether Amerikanistik as practiced in the GDR actually contributed to or impacted on the theoretical debates around American Studies. ${ }^{2}$ Acknowledging that German American Studies/Amerikanistik meant two different things for most part of its history also makes obvious how ideologically loaded a field of inquiry American Studies in Germany has been. However, I will not take a 
comparative view, which requires much more insight than I can offer. Nor can I add another revision of the field to those that have been published throughout its history. ${ }^{3}$ In fact, the very desire to revise and historicize is a crucial aspect of theorizing American Studies in Germany. ${ }^{4}$ Instead I have come to consider this the preliminaries for a book that may or may not be written. I will therefore suggest a possible historical trajectory, highlighting crucial moments and shifts in the debate in addition to identifying some major participants and singular contributions (while omitting just as many or more). ${ }^{5}$ First and foremost, however, I intend to raise questions and point to directions where the enterprise of theorizing German American Studies could move. To my mind, such a project, on the one hand, has to relate a historical narrative, a necessarily reductive story about the course of an ongoing discussion, while, on the other, it has to conceptualize a nationally and culturally specific contribution to a debate that is as much concerned with conceptions of culture, nation, and ideology as with the self-conception of a field that-in the context of German academia-keeps insisting on its exceptionality and exemplary nature. These are the balls that I am juggling, and, needless to say, narrative juggles easier than national contribution. While central terms of the debate-such as the concept of interdisciplinarity-were imported from discussions in the United States, they have been recontextualized, oftentimes gaining in significance, in German academic contexts. At the same time throughout its history, German American Studies has critically questioned the parameters from which American Studies in the United States has evolved-and this goes as much for the debates on methods of American Studies in the 1970s as for the current insistence on European or international perspectives within American Studies. ${ }^{6}$ As a consequence, the methods and theories that German scholars of American Studies have privileged and employed at different moments in the history of the discipline bespeak more than the discipline's self-conception. They also mark moments in the history of the sciences and dimensions of transatlantic, intercultural, and intracultural relations.

Before developing my argument, I would like to acknowledge the particular limitation of my view. First of all, I write this article as a scholar and teacher of North American literature and culture, not as a linguist, historian, or political scientist. Speaking for merely a part of the canon of disciplines engaged in American Studies makes a whole lot of difference to the narrative I relate. I also write this essay as someone who entered the university at a time when both 'old historicist' and structuralist models of reading cultural texts dominated the debates, even though the discussions about new methods of American Studies were in full swing; and I did so as someone who was way too ignorant to even notice. The time was the year Martin Christadler and Günter Lenz edited the special issue of Amerikastudien / American Studies entitled AmerikastudienTheorie, Geschichte, interpretatorische Praxis (fig. 2). Meaning to continue the debates begun in the Jahrbuch für Amerikastudien in 1973, this volume made evident that in 1977 the field of American Studies was in the process of a fundamental transition, due to both an extended notion of textuality and a new proximity to the social sciences. The collection included, under the heading of theory, essays on women's studies as educational strategy and new focus of American Studies (Hanna Beate SchöppSchilling), on new theories of American Studies (Günter Lenz), and on concepts of tradition in GDR Amerikanistik (Michael Höhnisch), in addition to explorations of "nonliterary media" (e.g. Thomas Elsaesser and Winfried Fluck), and "socio-historical interpretations of literary texts" (e.g. Heinz Ickstadt). Almost thirty years after its 
publication it is worthwhile recalling the agenda set by the editors. In the preface, Christadler and Lenz define American Studies as a movement of scholars of literature and the humanities who are attempting to break out of the traditional methodological and institutional boundaries of departments of English philology and history and establish the study of "America" as interdisciplinary cultural studies ("interdisziplinäre Kulturwissenschaft") ("Vorwort" 5). At the time, this enterprise called for modest cooperation between diverse disciplines as much as it envisioned a potentially integrating synthesis of different academic fields, crystallized by a common object of studies : American national culture. In any case, though, the project was meant to be exemplary : With their plea for a "true synthesis," which not only "integrates the disciplines" (Christadler and Lenz, "Vorwort" 5), but also aimed at overcoming the limitations of individual fields of inquiry (Kühnel 129), German American Studies scholars claimed to address a challenge whose character was considered a general problem in the history of the sciences and its theories. How to actually do interdisciplinary work, though, was a question that had yet to be solved : Divided into three parts, the essay collection still split theory and practice, literature and other cultural practices into separate spheres. Or, as Heide Ziegler aptly put it in 1984, in the 1970s American Studies became "the starting point for a methodological discussion that influenced the selection of specific cultural texts-not vice versa" (58). More specifically, while the inclusion of work on "non-literary media" and popular culture foregrounds the inclusiveness of American Studies and its conception of national cultures, the structural separation of this work from the reflections on "Wissenschaftstheorie und Wissenschaftsgeschichte" foreshadows a tendency, within theories of American Studies, to marginalize media studies and explorations of popular culture-a tendency that is currently being readdressed.

In retrospect, I see the schism in my own early academic interest, divided as it was between (women's) poetry and (poststructuralist) theory, in part as an effect of the very transformative moment crystallized by Christadler and Lenz's collection and perhaps best circumscribed by Bloch's concept of Gleichzeitigkeit des Ungleichzeitigen, of a synchronicity of the non-synchronic (whose new prominence ${ }^{7}$ is itself an effect of the paradigm shift within American Studies it allows to conceptualize). This was a moment when parameters of difference such as gender, race, and (to a much lesser degree) class had begun to evolve a line of critical work which positioned subjects previously relegated to the periphery of culture-subjects, that is, in the sense of both concerns/ issues and persons-right center stage, reclaiming or rather producing previously negated histories and cultural identities, while at the same time poststructuralist theories, insisting on différance, gained more and more precedence. Even if, in the context of German American Studies, the Derridean term needs to be understood as a trope for a variety of theoretical positions of which readers' response theory is as significant as Lacanian psychoanalysis, the question of how continental poststructuralist thought impacted on the practice of American Studies in Germany felt most urgent for many of us (who were then 'younger' scholars of the field). ${ }^{8}$ And impact it did, in multiple ways. In fact, as I will argue, with the emergence and growing dominance of parameters and politics of difference, on the one hand, and poststructuralist thought and notions of différance, on the other, the early debate on methods of American Studies, neatly tied as it was to the agenda of interdisciplinarity, transformed into discussions of theories of American literature, culture, history etc., dispensing with the 'problem' of interdisciplinarity on the way. Meanwhile, though, 
interdisciplinarity has returned with a vengeance. As theories of American Studies in Germany currently tend to refocus on literary studies and questions of aesthetics, interdisciplinarity has become the privileged approach for urgent-scientific as well as cultural-matters, an approach, though, mostly employed in areas other than American Studies.

6 Any revision of the processes of theorizing American Studies, therefore, has to trace the particular path taken when moving from a debate of methods of American Studies to an interrogation of theories of American literature, culture, and history, a move which itself entailed a revision of the plea for an interdisciplinary method. To reconsider these particular developments, interchanges, and transformations seems especially significant now that German American Studies faces a new shift within the field which seems to 'rediminish' its transdisciplinary potential to the practice of literary studies. While this shift in focus was an inevitable consequence of moving the debate from the (unsuccessful) search for one particular method of American Studies to interrogations of multiple theories of American literature and culture, it also underscores the fact that not only have American Studies always kept literary studies center stage. Theories of American Studies from the myth and symbol school to the New American Studies and (neo-)pragmatist approaches have capitalized on literary texts, thereby relegating to the periphery those media and technologies which, during the last fifty years, have changed cultural production and the social organization of culture dramatically. ${ }^{9}$

2. Clearing the Field

7 Any work that theorizes American Studies will have to rest on the assumption that there is a field that goes by the name 'American Studies,' a field delineated by more or less clear-cut boundaries. This, of course, is where problems begin. Or to put it another way : This is what theorizing American Studies is all about. "Theories are both models of explanation and attempts at legitimation," Winfried Fluck writes in the opening paragraph of his essay Theorien amerikanischer Literatur (1987), "attempts at ordering or positioning cultural material in a hierarchy which usually become necessary when the status and significance of a particular phenomenon has become indiscernible and contested" (1). ${ }^{10}$ Accordingly, one of the main functions of the early debates about methods of American Studies was to establish and position as well as to protect the field-a field which remains an endangered species within an academic atmosphere of decreasing resources for the humanities and social sciences. In retrospect, however, both the amplitude and extent of these debates-and we may today indeed wonder about the sheer length of some of the central essays published ${ }^{11}$-foreground the fact that the methodological debates also crystallized and channelled much more comprehensive political and scientific debates.

8 Thus we need to remember that theorizing American Studies in Germany has always been a highly political-or politicized-matter. More specifically, the political ambivalence that the rise of American Studies as an interdisciplinary field of inquiry into American cultural identity was inscribed within the United States was retained, though recontextualized, in the framework of post-War German academia. Institutionalized during the 1940 s and 1950 s, at a time that is, when the United States rose to super power status and processes of nation formation were deeply informed by the Cold War and by attempts at cultural conformity and consensus, American Studies had emerged in the United States, as Leo Marx recalled in 2002, as a left-leaning 
critique during the time of Depression and New Deal. ${ }^{12}$ Accordingly, early discussions about the potential and limits of interdisciplinarity addressed concerns which were fundamental to the agenda of Marxist (literary) criticism, such as the question of how literature and society interdepend (see O. Hansen 131). In turn, American Studies in Germany was both perceived as an emancipatory mode of inquiry and subjected to a thorough critique, which was as much an interrogation of critical theory as it was a transatlantic dialogue..$^{13}$ In its early stages doing American Studies and debating how to do it best clearly registered as a political practice and as part of the process of reconstructing German cultural and academic identity after the collapse of national socialism. This may explain, at least in part, why debates on the applicability of an American Studies agenda in Germany raised theoretical issues first as institutional questions-questions such as whether cultures should be studied as national or subnational phenomena (see Galinsky)-and why, generally speaking, methods of American Studies were discussed with a greater vehemence in Germany than within the American Studies movement in the United States. Whether explicitly or implicitly, theorizing American Studies has been one way to address as well as to drive the transcultural process known as 'Americanization,' a process that impacts on theory just as well. ${ }^{14}$ Thus theorizing American Studies in Germany meant negotiating complex cultural ambivalences : It acknowledged American culture-the culture of Germany's significant other in post-World-War-II times-as Kultur, voiced a critique of the American way, and addressed, in a highly mediated manner, the significant other situated beyond the 'iron curtain' running through German culture (an other that intensely interrogated its own other through the practice of GDR Amerikanistik.)

At the same time capitalizing on the relationship between the humanities and the social sciences, in general, and between literature and society or culture, in particular, the early debates on methods of American Studies touch upon a whole range of matters that fall under the rubrics of the theory and history of sciences (Wissenschaftstheorie and Wissenschaftsgeschichte)..$^{15}$ Introducing their volume on American Studies in Germany : European Contexts and Intercultural Relations (1995), Günter Lenz and Klaus Milich put it this way : "The failure to develop a method that could have grounded American Studies as a 'discipline' must be conceived of in the broader context of the humanities and social sciences as part of the general crisis of modernity" (Introduction 9). Any exploration of what it has meant to theorize American Studies in Germany, therefore, needs to resituate American Studies in the context of C.P. Snow's (Cold War) "two cultures" argument and Thomas Kuhn's The Structure of Scientific Revolutions (1962) ${ }^{16}$ while also making note of a continuous crisis discourse that has punctuated the practice of theorizing American Studies. What was the particular function of American Studies at this moment in the history of the sciences? And how long can a crisis discourse sustain a discipline that, as Ickstadt puts it, continues to conceive of itself "as still and always in the process of self-discovery and self-becoming" ("American Studies" 545)?

10 The question of whether there actually is a field that goes by the name American Studies thus necessarily provokes the commonplace observation that, of course, American Studies has changed during the last fifty years. Central to this change is the shift in terminology I have already hinted at. Whereas early American Studies ${ }^{17}$ talked about methods of interdisciplinarity, later discussions of the analytical scope of the field use the term theory and either refrain from making interdisciplinarity an issue or, more recently, privilege the term transdisciplinarity, acknowledging the lack of a 
center from which scholarship on American culture could possibly evolve. This displacement of one privileged prefix by another is itself an effect of both poststructuralist thought and critiques of difference, which owe part of their prominence, at least in Germany, to American Studies. Due to the fact that theory has tended to travel fast lately, parts of continental thought have been received more immediately in the United States before being sent back to be levelled and reassessed by German American Studies. In this way American Studies has had a considerable impact on the status of theory beyond the boundaries of its own field.

11 Significantly enough, while the early debates about the proper methods of American Studies helped to make German universities safe(r) for American Studies, the growing significance of theory led to an ongoing questioning of its national framework and to what some (mostly American) scholars take to be the gradual demise of the American Studies agenda. "American Studies is dead," an American colleague bluntly announced in mid-dinner conversation a few years ago. This 'crisis' of American Studies, marked most prominently by Janice Radway's provocative and much-debated address to the American Studies Association in 1998, resulted in part from the impact of poststructuralist and postcolonial theories. Viewed from this side of the Atlantic, however, the situation looks somewhat different, despite the prominence of transnational perspectives (see Kroes). Around here scholars have taken many clues from transnational American Studies and "insist," as Heinz Ickstadt does, "that American Studies should accept its name as its limitation and its boundary" ("American Studies" 554). Especially in view of the revitalization, since September 11, 2001, of American exceptionalism, cultural closure and self-referentiality, of new Anglo-American ties and processes of 'nation-building' as well as of new Cold War mentalities, (some) American colleagues' dismissal of American Studies seem undoubtedly premature. In fact, against many odds, both economic and political, we like to believe, as New Americanists Donald Pease and Robyn Wiegman do, that the significance of American Studies in Europe and Germany has increased since the end of the Cold War and, more significantly even, in post-9/11 times. Just like AIDS was the best thing that could have happened to the gay community, as some gay activists dared to claim in the late 1980s, the events of September 11 and their aftermaths gave American Studies a welcome, though short-lived boost. At the same time post-9/11 United States foreign policy may have done its share to increase the vulnerability of the field in a time of slim budgets. Currently well-travelled misconceptions about the limited scope and depth of American history and culture-misconceptions the American Studies movement in the United States and Germany has always been up against-prove to be as long-lived as the impact of the Frankfurt School and its perspective on (U.S.-American) cultural industries. ${ }^{18}$ Thus, American Studies seems to thrive first and foremost because we keep insisting that it does : engaging in certain scholarly work, in interdisciplinary dialogues, and in particular institutions (such as the German, European, American, and International Association of American Studies) (cf. Ickstadt, "American Studies" 552), redrawing disciplinary lines that we know have become quite brittle.

12 At the same time we need to distinguish between the ideal of American Studies as a platform for methodological and theoretical inquiries and its practice, which at most German universities has remained limited to Amerikanistik, the study of American language and literature (and culture, at best). ${ }^{19}$ Due to "[a] theory of literary history which was based mainly on a linguistic tradition," Robert E. Spiller once explained (14), 
the study of literature was aligned with linguistics rather than history, economics, or law, establishing a tradition that reinforced the institutional limitation American Studies-both as an academic pariah and as an exemplary exception-has always been up against. Thus when we emphasize that parameters of difference have fundamentally transformed the methods of American Studies in the United States and Germany, we tend to forget that American Studies itself still constitutes a difference within "the manor house of "English" and within more traditional ways of studying "History" (Galinsky 239). Accordingly, the boundaries of the field called American Studies have always been blurred and remain ever-shifting. From its very beginning the definition of American Studies as an interdisciplinary endeavour made American Studies, as Leo Marx recently reminded us, a "non-discipline" or, as he preferred to put it in the late 1960s, an "unscientific method"("On Recovering" and "American Studies"). The desire, on the part of some American Studies scholars, to make American Studies even more radically transdisciplinary, including the natural sciences in its disciplinary canon, may in fact add to its status as non-discipline in jeopardy even if it is geared, at least in part, to make American Studies live up to its own program. ${ }^{20}$ In addition, American Studies has become more contested because, due to a general increase of theoretical inquiry within the humanities and social sciences, the field has lost part of its exceptionality and can no longer claim a monopoly, neither on a more comprehensive conception of culture(s) nor on a particular up-to-dateness with regard to methodological debates. Appropriating terminologies that evolved, at least in part, from feminist, gender, and African American Studies, ${ }^{21}$ postcolonial criticism and theories of New English Literatures meanwhile cover a lot of ground, including debates on multiculturalism, hybridity, and transnationalism, ground which is shared with the disciplinary scope of North American Studies. ${ }^{22}$ Unlike the New English Literatures whose interrogations thrive on theories of difference and diversity (cf. Isernhagen, "American Studies" 165), American Studies necessarily keeps returning to its specific national framework. In view of the current 'rebirth' of the nation, this may not be a bad idea after all.

3. Kultur, Culture, Trancultural Complexities

13 Even though German Amerikastudien had their beginnings in the 1920s, American Studies was clearly a post-World War II phenomenon, as Andrew Gross poignantly put it in conversation. Theorizing American Studies thus necessarily examines the complexities of post-war transatlantic relations and explores the field as an arena where differences of cultural and academic traditions have been played out without necessarily affecting the political relations they undoubtedly involve. And again, this may hold even more true for studies of American literature and Landeskunde as they were practiced in the GDR. American Studies/ Amerikanistik in Germany is certainly unthinkable without the work of those Americans, who from the 1930s on, turned against the methods that dominated English departments in the United States, some of whom became either major representatives of the American Studies movement or central figures in the study of American literature and culture like F.O. Matthiessen, Robert Spiller, Henry Nash Smith, Richard Chase, Leo Marx, and Leslie Fiedler. And yet the rise of American Studies in Germany was by no means a one-way enterprise. German academia, so goes the claim, had already prepared the ground for American Studies. "[L]ong before American Studies knocked at the door," Hans Galinsky emphasized in 1964, area studies-Oriental, East European and Iberian studies-had entered German academia and fields such as cultural philosophy and cultural history aimed at the study of "whole cultures" (232). At the same time the American Studies 
agenda was in many ways incompatible with German notions of Kulturwissenschaft, partly due to nationally specific definitions of culture and Kultur. Thus, if American Studies meant to establish a form of interdisciplinary Kulturwissenschaft, theorizing American Studies would also mean to address this fundamental conceptual difference.

While some (American) American Studies scholars kept insisting that their German colleagues had particularly informed insights into the nature of culture-“[p]robably no national group of scholars," Spiller claimed, "has so well considered and tested a tradition for the study of culture, whether as a whole or in its parts, as have the Germans" (12) - to many German academics American culture spelt 'other' and otherness, mind you, was not yet a privileged position. To institutionalize American Studies/Amerikanistik in Germany, therefore, meant to place a highly successful, yet supposedly inferior culture center stage, thereby necessarily renegotiating the privileged position of European and, more particularly, of British culture, as well as taking issue with perspectives on mass culture and cultural industry disseminated by the Frankfurt School. Thus, doing and theorizing American Studies in Germany not only meant to assert American culture as Kultur, but also to call into question clear-cut distinctions between high and popular culture..$^{23}$ Any reconsideration of German American Studies and its methodological framework has to readdress and theorize these early debates, testing the complex concepts of transculturation we have evolved in the meantime.

15 The complexities involved here become even more evident once we remember that distinctions between high and popular culture had only recently been blurred by notions of a völkische Kultur propagated by German national socialist ideology, which rejected modernist art as degenerated and dismissed jazz as Negermusik. Despite obvious ideological differences American Studies and critical theory, by contrast, shared a formalist sense of art which fundamentally reevaluated high modernism (while neither cared much for Harlem Renaissance culture ${ }^{24}$ ). Given both the tendency of German political philosophy toward radical dissent and the dominance of critical theory's modernist notion of Kunst and Kultur, it is evident why cultural studies did not get off the ground easily-if at all-in Germany, but has thrived in Great Britain. Much less concerned with working-class cultures and subcultures, American Studies still allowed for different notions of 'classical' literature and, eventually, for debates on race and ethnicity which entailed an-at least implicit-revision of Germany's own 'race problems. ${ }^{25}$ In fact, it is noteworthy that American Studies/Amerikanistik in both parts of Germany have put a particular emphasis on the study of minority, first and foremost on African American and Native American, cultures, even if these studies were politically legitimized in different ways and performed from highly different ideological vantage points. ${ }^{26}$ If one reads this shared and continuous interest as a mediated interrogation of Germany's own history of racial discrimination and genocide, yet another culturally specific function of American Studies in post-war German academia comes to the fore, highlighting the 'darker' dimensions of the interdependencies of German and American history, many of which remain to be explored and theorized.

16 Due to distinct histories American and German scholars clearly parted when it came to conceptions of national culture. At a time when American Studies began to construct an American past, including a canon of American literature 'usable' for national selfconceptions, German philology and area studies tried to steer away from a national 
agenda and developed a "preference for supra-national phenomena" and a sense that “"culture communities' cut[...] across national boundaries."According to Galinsky, neither German Romance philology, which included European as well as South American literatures and languages, nor German studies ever "provided for anything similar to 'American Studies"' $(242-43,241,243)$. To make up for this deficit German scholars were expected to add their legendary skills in conceptual thinking. "Where theory was needed, it could be borrowed from German scholarship," Spiller put it, venturing "generalizations about national character and national scholarship" when addressing the German Association for American Studies in 1959 : "You have, probably far more than any other people, a tendency to look at human experience in terms of absolutes and to clear your theoretical positions before proceeding to empirical practices." This knack for theory, Spiller suggested, could do much good for American Studies : "The pragmatic approach of the Americans may help to bring the more nearly a priori approach of the Germans into closer bearing with the facts of the given situation in time and place, but the German approach should continue to offer, as it has in the past, much of the theory for the movement" $(12,11,12-13)$.

Partly due to the occasion, Spiller calls upon Germany's reputation as nation of "thinkers and philosophers" and projects American Studies as a German-American joint venture. Similarly, in a 1977 interview published in Amerikastudien, Henry Nash Smith confessed that "almost by instinct, in this country we are less, far less theoretical than the Germans" (qtd. in Lenz, "American Studies-Beyond the Crisis?" 54). While Olaf Hansen speaks of a "theoretical abstinence" pertaining to Spiller's (and Nash Smith's) essays on methods which position American Studies in a liminal space between "social and humanistic scholarship" (144), Lenz stresses that matters are not as clearcut. Responding to Smith's claim he observes that American Studies in the United States tends to increase the volume of theoretical debate when German scholars turn away from theory, thereby foregrounding "the significance of the interaction of theory and practice in the two countries" ("American Studies-Beyond the Crisis?" 54). ${ }^{27}$ Interestingly enough, by the 1990s, in part inspired by American philosophers from Stanley Cavell to Cornel West to Richard Rorty, German American Studies scholars reengage American pragmatism and read, as Fluck and Thomas Claviez do in 2003, all practice of American Studies as (being informed by) theory (see Introduction x-xi). (In its final consequence such reassessment makes scholars who have explored the meaning of 'America' by illuminating readings of American literature and culture our most significant theorists. Theorizing German American Studies, in turn, becomes a highly comprehensive undertaking.) Unfortunately, though, this reassessment of theory, pragmatic and convincing as I think it is, drags behind it the familiar binarism : Raising "the interesting question whether-and to what extent-recent developments in American Studies have undermined the possibility for a more systematic analysis of "America," Fluck and Claviez hasten to provide their own answer : "[A]t present more than ever, the way in which non-Americans encounter American society and culture is not through multiple selves and happily hybridized border cultures but in a more systematic form" (xii). In an essay collection that prominently features work by Americans this claim may come as a surprise. It seems to voice a resistance against the fact that, as Ickstadt puts it, "[...] the idea of a particularly American difference" has been a creative resource that "has exhausted itself and is now being replaced by a drive toward ethnic [and other kinds of] self-assertion." It may also be another way of saying that "institutionally speaking, American Studies, in a strict sense, has almost 
disappeared in the U.S." ("American Studies" 550-51). Given the fact, though, that German American Studies scholars, like their American peers, have engaged "multiple selves" and "border cultures," the distinction being made here also draws a fine line within German American Studies. Projecting an intra-cultural difference as a difference between (American and non-American) perspectives, the 'interesting question' the editors have raised unmistakably pinpoints the transcultural complexities involved in theorizing American Studies.

4. Are We Being Transdisciplinary Yet?

18 Aiming at the study of the interdependencies of literature, culture, and society, American Studies defined itself as an interdisciplinary endeavor and made interdisciplinarity part of its agenda as projected in the late 1940s. By the 1960s, though, interdisciplinarity seemed an ideal rather than an actual scholarly practice to German critics. Delineating the scope of the field in 1964 Galinsky, for instance, voiced his doubts about American Studies' capacity to synthesize the "efforts and achievements of individual disciplines." Instead he believed that "[t]he 'unity' of American Studies would seem to rest in the Americanness of the initial problem posed and in the cooperative effort to solve it, but not in the method applied to solving it" (Galinsky 237, 238-39). It comes as no surprise that once common notions of "Americanness" were no longer to be had, American Studies lost its bearings. In fact, though, American Studies seems to have been in constant peril. "In the 1960s," Lenz explains, "this crisis arose out of a critique of the political shortcomings of American Studies and was related to a lack of 'methodology' or 'philosophy' that would integrate the perspectives of the various disciplines contributing to 'the study of American culture, past and present, as a whole,' (H.N. Smith) into an interdisciplinary project" ("American Studies-Beyond the Crisis?" 57). Echoing American perceptions, the crisis culminated in the 1970s. ${ }^{28}$ "For the first time," Lenz recalls in 1982, "American Studies was threatened in its very existence" ("American Studies-Beyond the Crisis?" 57). When Lenz and Milich claim that "[s]ince its beginnings, American Studies inside and outside the United States have undergone a serious crisis of legitimation" (Introduction 9), they not only underline how central the term 'crisis' has been to theorizing American Studies. They also acknowledge the productivity of a term which deserves closer analysis. For if we trust that postmodern crisis discourse, as Jean Baudrillard argued, aims to reaffirm the reality principle whose loss it bemoans, a sense of constant crisis keeps reassuring German American Studies of its unquestionable significance.

Until the 1970s American Studies' lack of a specific and singular method-a lack that Spiller in 1959 still interpreted as "one of [American Studies'] major strengths" (17)_ posed itself as the central 'problem' of American Studies (Fluck, "Das ästhetische Vorverständnis" 111). Robert Berkhofer calls this ailment "methodenschmerz" ("Problems" 159). And even if the debate about methods indeed established the field, it failed to transform its programmatic plea for interdisciplinarity into a particular approach. Nor did it result in a predominantly interdisciplinary scholarly practice. While the assumption was that certain methods-somewhat 'naturally' or necessarilylead to transdisciplinary approaches to American culture, their very discussion frequently culminated, as Lenz underlined, in the reaffirmation of "practical or substantive work," the "identification of [the] rationale [of American Studies] with a few books by its major scholars" ("American Studies-Beyond the Crisis?" 53). German Americanists, Heide Ziegler suggested, made American Studies "the paradigm for 
interdisciplinarity in the form of a hermeneutic method" (56). At the same time, the insistence on interdiscisciplinarity also foregrounds, as Olaf Hansen argued, "that the dichotomy between the Sciences and the Humanities (causal explanation [Erklären] vs. interpretative understanding [Verstehen]) has fundamentally influenced the discussion of theory and method in American Studies" (130). It forces us to see the impact of American Studies in the context of a new definition and reevaluation (Aufwertung) of the humanities vis-à-vis the sciences and the social sciences (133). Part of the value ascribed to the humanities was their transdisciplinarity, the fact that they were less concerned with methods and theories, and not as much focused on particular technological and economic goals and revenues as the sciences and social sciences. Needless to say, this assumption has sufficiently backfired and successfully served to legitimize the consistent underfunding of the humanities and thus sealed what is perceived as their increasing irrelevance (Hansen 134). ${ }^{29}$ More significantly, though, in view of this belief, the rise of theory in the 1980s reads as a rise in authority and significance for literary and cultural studies.

Attempting to bridge the gap between the humanities and the social sciences, the early debate on methods of American Studies, Olaf Hansen argued, pointed into two juxtaposed, yet interrelated directions. On the one hand, American Studies seemed to favor the methodological ideal of the exact sciences ["scientifische[s] Methodenideal"], on the other, it attempted a synthesis that accounted for both traditional scientific standards and the function of (all) sciences in a democratic society (139). ${ }^{30}$ The very practice of American Studies thus was-and still is ${ }^{31}$-projected as a symptom of democratization $(141,142)$. (To interpret the rise of Anglophony, in turn, as a kind of [re-]colonization is tempting, yet certainly shortsighted. After all, its new prominence is partly due to the prominence of certain theories that American Studies helped to disseminate). In 1973, Hansen criticized the idealism and ideology entailed in this alliance of American Studies and democracy, projected by the 'founding fathers' of American Studies. "When seen against the background of this dichotomy [of sciences and humanities]," he wrote, "the first attempts to provide American Studies with a theoretical basis of its own by means of interdisciplinary synthesis (e.g. Tremaine McDowell) must be characterized as a form of optimistic idealism bordering on ideologically determined self-deception." Moreover, Hansen emphasized that the desire to synthesize distinct disciplines fails to acknowledge the specificity of methods and opted for dialectics instead. Distilling from the work done in American Studies "five distinct paradigms of differing explanatory value"-the pragmatistic, functionalist, symbolic-interactionist, and historical-hermeneutical paradigm and that of "radical American Studies" (Hansen 130) ${ }^{32}$-all of which attempt to delineate the interdependence of literature, culture and society, Hansen claimed that "not a purely additive but rather a dialectically modified combination of the last three paradigms is most capable of providing American Studies with a suitable theoretical framework for the development of its methodology and practice." I am quoting at length here, because I find it worthwhile to remember-once again (see Ziegler 59)-this insistence on dialectics as well as the distance we have travelled in the meantime. Dismissing a "selfsufficient contemplation of metatheoretical questions" Hansen aimed at a method which provided "a context for practical work in literary criticism" (130). Unlike theories which develop a system (or systems) of hypotheses to frame and explain natural or cultural phenomena, methods mean to enable scientific or scholarly work by projecting a systematic way of approaching a specific question or problem. In the field 
of American Studies this distinction is crucial; because the move away from methods, in the 1980 s, on to theories also marked a movement away from the national paradigm.

21 While some scholars, like Galinsky, more or less dismissed the question of methodology and others, like Hansen, opted for a dialectical approach, Fluck aimed "to determine what has so far prevented American Studies from carrying out its interdisciplinary intentions," yet focused on literary studies. Pointing to the discrepancies between debates on methods of American Studies and actual analyses of American culture, Fluck underlined that American Studies is not to become more interdisciplinary by displacing one method by another. Interdisciplinarity was not a matter of finding the right method. Nor was American Studies short of methodological inspiration. Its limitations, Fluck argued, were due to the effects of unacknowledged "contextualist" preconceptions and value judgments ("uneingestandene kontextualistische Wertprämissen") ("Das ästhetische Vorverständnis" 110, 111). ${ }^{33}$ According to Fluck, the central obstacle to interdisciplinary work was that while attempting to move beyond formalist notions of text and context, American Studies relied on more than just "the notion of structural unity as indispensable." It also projected this unity from the literary text "onto society rather than viewing the latter in its own right," thus conjuring up an ideal rather than an idea of American culture (Fluck, "Das ästhetische Vorverständnis" 110, Theorien). Despite its "attempts to extend 'new criticism' towards a "new historicism," American Studies thus failed to open up for cultural contexts and erected disciplinary boundaries within a supposedly interdisciplinary field. In order to become truly kulturwissenschaftlich, Fluck claimed, the contextualism (Kontextualismus) of early American Studies had to be given up ("Das ästhetische Vorverständnis" 110, 128-29). Curiously enough, employed in this context the term "new historicist" (then associated with the work of Murray Krieger and Roy Harvey Pearce, among others) already foreshadows the New Historicism of the 1980s, which meant to rehistoricize literary studies and enable interdisciplinarity, yet tends to echo the fallacies of formalist literary analyses.

22 As contrary as Hansen's and Fluck's interventions may be, they are also complementary, as Ziegler noted (59), and comparable : Both still consider interdisciplinarity a central methological concern; both stress the significance of aligning explorations of aesthetic practices with complex conceptions of cultural and historical contexts while acknowledging that interdisciplinarity does not follow from a synthesis of methods; and both map the routes along which American Studies steered away from interdisciplinarity, one that turned to theories of literature, another that led to theory proper. Yet to do interdisciplinary work primarily means to approach a scientific or scholarly problem or question with a number of methods or theoretical perspectives and through the practice of more than one discipline. This, of course, requires us either to be familiar with the methods of several fields of inquiry or to allow other scholars to provide that expertise. Since very few of us are versed well enough in the methods of more than one discipline and communication across disciplinary lines continues to be a challenge, interdisciplinarity only rarely becomes a practice and oftentimes remains a theoretical ideal. "American Studies," as Fluck and Claviez define the field in 2003, "is a joint, interdisciplinary academic endeavor to gain systematic knowledge about American society and culture in order to understand the historical and present-day meaning and significance of the United States" (Introduction ix). The collection of essays on "Theories of American Culture, Theories of American Studies" introduced in this way, authored by scholars who teach in 
departments of English or at (English and) American Studies institutes, hardly lives up to this programmatic plea. Rather remembering that American Studies is meant to be a "joint, interdisciplinary academic endeavor" has become a ritual we all practice, a refrain we keep repeating and conjure up as a mark of difference, while much of our work, focused first and foremost on either literary and cultural or historical analyses, tends to fall under the rubric of multidisciplinarity at best. As we keep acknowledging the necessity of approaching our object of study and research-United States American culture-from more than a singular disciplinary venue, we nonetheless situate American Studies in close proximity to current interdisciplinary research that cuts across the institutional boundaries between the sciences, humanities, and social sciences. American Studies may come closest to this kind of work when it examines new media technologies and popular cultures, to name only two fields of inquiry which project the future of American Studies while reconnecting with its innovative, emancipatory methodological "roots." ${ }^{34}$ After all, there are not only interests shared by American Studies and the sciences, as I have argued elsewhere; there are also questions whose complexity require transdisciplinary research (see Sielke, "Science/Fiction"). American Studies may indeed profit from both consulting interdisciplinary work done way 'outside American Studies' and theorizing its own transdisciplinary practice.

5. Difference/Différance

Until the 1970s the search for a method of American Studies was first-both necessarily and understandably-guided by a desire to reduce the diversity of American multiculture to some degree of unity or consensus, a consensus that in the 1970s was questioned by pointing to the 'realities' and conflicts within that culture. However, as Lenz stresses, even though this critique of the ideology of American Studies, its alliance with Cold War politics and its tendency to perpetuate American exceptionalism transformed curricula and began to shift the emphasis to "American Culture Studies" (Lenz and Milich, Introduction 11; cf. Lenz, "American Studies-Beyond the Crisis?" 58), it had little impact on the formation of theories. Instead it was the rise of poststructuralist thought and the effects of a politics "from the margins," which from the late 1960s onward impacted on the humanities and social sciences in general and American Studies in particular. This growing insistence on différance and difference, on the one hand, provided for the radical critique that was called for in the late 1970s and early 80s. On the other, it eventually caused yet another 'crisis' of American Studies in the 1990s, a 'crisis of the crisis,' if you like. Or as Lenz and Milich put it in 1995 : “[t]he crisis of legitimation has been replaced by a crisis of representation" (Introduction 9). After all, who could bemoan the lack of "methodological coherence at all three levels of theory, method, and technique" (Robert Meredith, in 1973) or "the absence of a coherent American Studies 'philosophy"' (Sklar qtd. in Lenz, "American StudiesBeyond the Crisis?" 55, 59), when the very ideal of coherence had lost its potency? In fact, one seemingly paradoxical effect of the 'rise of theory' was that hopes for a 'right' approach to American culture were ultimately lost. Theories were diminished to particular, local perspectives on the world, to kinds of narratives which in turn resulted in a decrease of the 'resistance to theory' characteristic, for instance, for early feminist criticism (see Showalter). Theory became a way of making one's positions clear, of acknowledging-as best as one can-the assumptions that underlie one's interpretations of culture. 

early 1970 s or the fundamental shift in theoretical thought that goes by the name 'linguistic turn' and calls up the names Jacques Derrida, Jacques Lacan, Michel Foucault, Julia Kristeva, Luce Irigaray, and Hélène Cixous, among many others. Suffice it to say that deconstructivist language philosophy, revisionist psychoanalysis, and discourse analysis interrogated established conceptions of self, identity, and author, experience and reality, culture and nation. Interrogating these conceptions-central to American Studies-they evolved new notions of subject, text, and world, which first affected literary and cultural studies before impacting on the study of the social sciences and, albeit to a much lesser degree, the sciences. Significantly enough, poststructuralism renegotiated terms such as experience, truth, and identity at the very moment when feminist and African American perspectives reclaimed positions of otherness as modes of identity. Accordingly, feminist critics and scholars of gender studies, in particular, wondered why at the very moment women and other culturally and politically marginalized groups asserted their own sense of self, body, and identity, these concepts -and the very sense of presence and authenticity they entailed-became highly contested..$^{35}$ The fact that once women, African Americans, and other 'others' venture out in search of their bodies and selves, theory steps in and dismisses such endeavors as futile, easily appears as a perfect example of patriarchal plotting.

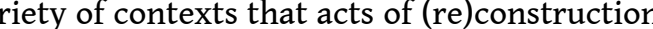
and deconstruction should not be seen as oppositional, but as interdependent processes. In fact only the gradual deconstruction, throughout the twentieth century, of the male philosophical subject and the insistence on the discursiveness of identity and history has enabled supposedly marginal figures to take center stage and rewrite themselves into history as subjects. The very insight that subjectivity is discursive, performative, and processural has done away with stability, yet allows for and invites a strategic use of subject positions and political vantage points to be claimed temporarily and for particular purposes. Accordingly, conceptions of gender, class, race, and ethnicity have transformed fundamentally. In fact, the interdependence of poststructuralism and revisionary literary history, of theories of différance and difference may become most evident once we call to mind what transformations the category gender underwent as we moved from women's studies/feminist criticism to gender studies. First considered essential assets and part of the expressive register of particular social groups, parameters of difference and identity were reassessed as effects of specific discourses in the late 1980s and early 1990s. Accordingly, the analysis of cultural practices no longer aimed at the ways in which literary and other cultural texts offer truths about the nature of American culture. Rather what these texts project as American culture's presumed 'true nature,' in what ways and to what (political) ends became crucial questions for American Studies.

Even if the debates on difference and différance did not evolve from the center of an American Studies "community," their privileged terms responded to questions American Studies had posed in the 1970s, questions at the core of which was the relation of text and world, on the one hand, and the heterogeneity of American culture, on the other. Accordingly the emergence of difference/différance fundamentally changed the agenda of American Studies in the United States and Germany while also being reflected upon critically-with (distant) continental perspectives on the American reception and recontextualization of (close-to- home) continental theory-in 
German American Studies. It is in part an achievement of American Studies and the 'Americanization' of cultural analyses, including conceptions of genre, ${ }^{36}$ that German scholars got familiarized with both the paradigm shift in theory and a politics of difference and multiculturalism. Most significant, though, may have been the impact of women's and gender studies on theories of American Studies in the United States and in Germany as well as on public debates of gender matters. ${ }^{37}$ The scope of this impact may be assessed by recalling the German reception of Judith Butler's work (see Gernalzick). Delivering lectures in Frankfurt and Berlin in the early 1990s, Butler confronted her audience with a rhetoric and mode of thinking foreign and unfamiliar to many of her listeners, some of whom sympathized with Butler's feminist agenda, yet tended to resist her appropriation of 'male discourse.' As a consequence, the philosopher frequently felt obliged to clarify her arguments, commenting on the many misunderstandings caused by her public appearances in German daily newspapers. I do not mean to suggest that German American Studies scholars necessarily found Butler's lectures transparent; however, we came prepared for the ride..$^{38}$

Likewise noteworthy in this context is the prominence, within German American Studies, of theories of postmodernity whose concepts are inseparable from, yet by no means identical with, poststructuralist thought. Even if we have acknowledged postmodernism as a transnational phenomenon of globalization, the term was quite "unknown" (Ruiter 360) to literary studies in Germany before American Studies introduced German audiences to American postmodernist fiction. The project of theorizing German American Studies may therefore profit from reengaging (West) German scholars' work on postmodern American literature and culture ${ }^{39}$ as well as the debate of postmodernism and poststructuralism in the GDR, a debate which emerged comparatively late, as Utz Riese admits, yet not too late to be remembered as part of a fundamental cultural and political turning point. What makes such revision particularly worthwhile is that it has to interrogate the affinities between certain literary and cultural writing practices, on the one hand, and certain theories of reading and their inherent cultural ideologies, on the other. Theories evolve from specific cultural contexts and in dialogue with privileged texts, which, after the new criticism, tended to be narrative rather than poetic, ${ }^{40}$ while the term poetics has in turn been appropriated to conceptualize the aesthetic and political effects of all kinds of cultural discourses.

of course, there have been readers who resisted both deconstruction and parameters of difference. Fluck's excellent essay Theorien amerikanischer Literatur (1987) may serve as case in point here. Providing a concise account of how American literature has been read, moving from D.H. Lawrence's Studies in Classic American Literature across the myth and symbol school and their critics to poststructuralist approaches, Fluck convincingly reasons that deconstructivist readings tend to reduce literary texts to allegories of deconstruction itself and diminish the "play of the signifier" to highly uniform interpretations, to a singular allegory : the unreadability of all texts. At the same time, his own argument tends to reduce deconstruction to a method of reading literary texts, which, in turn, sets the stage for presenting his own reading method as a theory of American literature. If, on the one hand, we strip deconstructivist reading practices of their political potential while, on the other, letting the debates on canons and inclusions of minority literatures and popular cultures amount to little more than political moves, we are indeed left with a binarism which calls for more compelling analyses-analyses the author has certainly provided us with : Positioned, in 1987, as a 
mode of interaction between poetics and hermeneutics and as continuous with the work of the Constance School, Fluck's theory of reading has evolved a most persuasive account of the changing functions and aesthetic effects of late eighteenth- and nineteenth- century narrative fiction (Fluck, Das kulturelle Imaginäre). I wonder, though, how this functional model of American literature would go about reading modernist and postmodernist texts which not only explode the consensus that nineteenthcentury texts renegotiated, but also expose the aesthetic strategies that realist texts, in particular, aim to downplay. More significant, though, in this context : Why not acknowledge that theories, like literary texts in their particular contexts, have their own specific cultural functions?

Thus Fluck's intervention, in fact, invites us to remember the distinct functions of poststructuralist theories and parameters of difference. If we take différance and difference as two sides of the same coin, theorizing American Studies could also mean to make more explicit the theoretical dimensions inherent in and fundamental to the canon debates, debates which are effects of a politics of difference (and which Perry Miller considered exhausted by 1962). While the revision of the canon has preoccupied literary studies in general, it has certainly dominated a significant part of the American Studies agenda from the mid-1970s to the early 1990s, evolving new anthologies and a huge body of revisionary literary history. ${ }^{41}$ In the context of theorizing German American Studies such reconsideration moreover invites intracultural perspectives. While American Studies/Amerikanistik in both parts of Germany focused on 'minority' cultures, be they Native or African American, they obviously did so from divergent political vantage points and consequently "warred" with partly divergent canons of American literature. Denouncing the decadence of modernist texts, East German scholars of American literature at the same time celebrated Native American and African American literatures. Moreover, their search for a usable concept of an American literary tradition employed 1930s working-class novels, whose authors many American Studies scholars west of the 'iron curtain' may not have been all that familiar with. In 1977 it was still possible to argue that Americanists in the GDR framed their work "as part of a worldwide process of historical change" in the course of which "a cultural revolution will transform human "praxis" and "national literatures will be transcended in the direction of a world literature" (Hoenisch, "Zum Begriff der Tradition" 104). Needless to say : politically, things turned out somewhat differently. Yet the concept of world literatures has survived, even if we privilege the term postcolonial literatures now.

The growing significance of such transnational perspectives has been a mixed blessing, though, for American Studies. Extending the perspectives of postcolonial criticism and New English Literatures to North America, ${ }^{42}$ the empire (of English studies) seems to write back indeed. But so does American Studies as it metamorphoses into global studies here and there. ${ }^{43} \mathrm{~A}$ particularly European vision of the futures of American Studies would be to take up the suggestion-put forth by postcolonial perspectives, debates on transnationalism, and the economic realities of NAFTA-to transform American Studies into a comparative enterprise (see Porter), thereby allowing for plural positions while at the same time acknowledging the particular (inter-)dependencies of these three nations. Taking Canada, the United States, and Mexico as mutual points of reference, the study of North American cultures can focus on paradigmatic moments and representations of a shared history and culture of colonization, nation building, immigration, multiculturalism, diaspora, and 
globalization. It can examine how these processes have played out differently in each of these cultures and, more specifically, how social and cultural hierarchies and ethnic differences are borderlines imposed on and within bodies in culturally and nationally specific ways. Focused on transdisciplinary micro-histories, it can, as Gesa Mackenthun suggests in a different context, keep in mind the "macrostructures of inequality and injustice that cut across boundaries" (235). Moreover, explorations of the (literal and figurative) borderlands in the South of the United States help to map the-entirely different-borderlands in the North more clearly. And the crossing of these borders, both the borders of culture and those of disciplinary conventions, will necessarily open up new perspectives on transatlantic relations.

Once again, though, these directions recently envisioned for American Studies constitute, to a certain degree, a return rather than a turn, taking up paths already outlined in the early 1980s, paths that even envisioned "turning American Studies potentially into World studies," into an early version of global studies. "To be sure," Lenz insisted in 1982, "American Studies has to become more "comparative' and "crosscultural,' more 'international,' [...] but this should not be mistaken for a new 'philosophy' that could per se give direction to American Studies and define its scholarly directions" ("American Studies-Beyond the Crisis?" 60). Even Lenz's advice still applies. If we transform American Studies into North American Studies we do, in fact, change direction. Since the United States, Canada, and Mexico offer different answers to questions of globalization, such change may turn out to be promising. A field called "comparative North American Studies," however, would also require closer cooperation with English studies, Romance languages and literatures, and Latin American Studies. Can we indeed transcend these disciplinary borderlines? Can American Studies learn from Canada? Or from Canadian literature, which, as Ickstadt points out, positions itself "in terms of the national and-perhaps even-as the postcolonial"? Could American Studies achieve what Canadian studies, even in Canada, failed to achieve : the productive institutional alliance of English, American, and Romance studies? Or would we simply run the risk of "overextending the boundaries of the field" big time and experience the rise of new boundaries? (Ickstadt, "American Studies" 560, 553; cf. Claviez, “Whose 'American' Century?” 259).

In any case, the debates on a "new North American Studies" 44 highlight that the most crucial effect of theories of difference/différance on the field American Studies amounts to the deconstruction of the term/concept/project 'America' and its reconceptualization as a transnational and global phenomenon, or, if we follow Baudrillard, as deconstruction (see Haverkamp). Having redefined America in this way we can recover American Studies as the force of a deconstructive-that is both destructive and inherently democratic-process that America itself cannot be but a part of. This does not mean that we have to do without American Studies. Yet it means that doing American Studies requires a large dose of negative capability.

6. "Always Historicize!"-But with a Difference

33 From its very beginning, history-next to literature and linguistics-has been the most significant discipline within the canon of fields that make up American Studies in Germany. However, notions of how history is defined and, as a consequence, how one is to 'do' history have changed, affecting the work of scholars of American culture and German historians concerned with United States history. ${ }^{45}$ In the field of literary and cultural studies this development may best be traced by following the transformations 
the term 'context' went through as we move from new critical to new historicist perspectives. While context meant (all parts of the) structure (of a literary text) to the new critic, it was identified with so-called external or factual reality in old historicist analyses of the 1970s (see Berkhofer, "Problems," "New Context"). As poststructuralist perspectives reconceptualized texts and political institutions as discourses-"in the absence of a center or origin, everything became discourse," Derrida famously wrote in 1966 (110) - context was redefined as a network of diverse cultural texts, including legal and medical documents as well as literature, in new historical analyses of Renaissance culture in the $1980 \mathrm{~s}^{46}$ Questions of aesthetic value-secondary since "the ever-critical French discover[ed] that everything always happens everywhere but it's all the same" and "structuralism [was] born" (fig. 1)-became even less relevant. Accordingly, new historical perspectives accelerated the transformation of literary studies into cultural studies ${ }^{47}$ Insisting on the textuality of history, scholars acknowledged the status of history as narrative, as a kind of fiction. ${ }^{48}$ History also ceased to be a singular narrative told from a supposedly consensual point-of-view and became many, oftentimes conflictual histories. Thus unlike Fredric Jameson, who urges his readers to "always historicize," yet still favors "History with a capital ' $\mathrm{H}$ "' (Lenz, "Reconstructing" 27) and therefore may conclude that postmodern culture has dispensed with subject and history, new historical perspectives force us to acknowledge that what postmodernity in fact dispenses with is historically specific notions of subjectivity and history.

This shift from old to new historicist perspectives coincided with a "reawakened interest in 'history,' 'politics,' and 'society"' (Lenz, Keil, and Bröck-Sallah, Introduction 9) prominent, for instance, in the New American Studies, which readdressed conceptions of 'America' and its ideologies by rereadings of American literary texts, readings that were inspired, to different degrees, by a poststructuralist emphasis on rhetoric, theories of cultural difference, new historicism, as well as the new exceptionalism of the late 1980s (Lenz and Ickstadt). These novel tendencies in literary and cultural studies were promoted as enabling both a "historical and political turn" (see Fluck, The Historical and Political Turn ) and a new interdisciplinarity-Günter Lenz, Hartmut Keil, and Sabine Bröck-Sallah carefully speak of "the possibilities of an interdisciplinary discourse that has grown out of [...] changing and more flexible approaches within the disciplines" (9). If we want to assess the impact of this "historical and political turn" of the mid- to late-1980s and early 1990s, though, we need to distinguish two different, in fact, opposite tendencies. While new historicist analyses employ poststructuralist perspectives for synchronic analyses of paradigmatic moments of cultural history, attempts to rehistorize also resisted what was perceived as the continuous sameness of critical analyses focused on écriture and processes of signification as well as what for some scholars of history appeared to be the concept of an increasingly fragmented American culture.

In a more general sense, though, the terms rehistoricization and repoliticization seem to imply that, unlike theories of difference, which appeared preoccupied with heterogeneous histories and (identity) politics, poststructuralism had veered away from 'real' history and politics. This, however, proved to be a highly debatable assumption, nurtured in part by the notion that deconstruction was merely a method of reading literary texts. In fact, though, poststructuralist analyses-be it the work of Derrida, Kristeva, Barbara Johnson, or Henry Louis Gates-have deeply transformed notions of the political, insisting that certain practices of writing and reading are in themselves historically specific and political (cf. Lenz, "Reconstructing" 32-40). 
Accordingly, the supposed "ahistoricity" of French feminist poststructuralism was the effect of misreadings rather than of naïve essentialist postulates on the part of its protagonists (see Sielke, Fashioning). In view of this political and historical dimension of theories of difference/différance, it always struck me as odd that New Historicism set itself up against (while at the same time echoing) nineteenth-century notions of historicism and new critical formalism, just as if the debates that separate Cleanth Brooks from bell hooks never even took place. Yet theorizing seems to require this kind of forgetting and misreading, which, time and again, allows to suggest that critical inquiries are taking a turn (for the better, of course), while in fact ideas, concepts, and terminologies are constantly being recontextualized and so-called turns turn out to be returns ever so often (though we are never taken to the same place twice, of course).

The term New Historicism itself was hardly new, originally associated, as Fluck points out in 1973, with the work of Krieger and Pearce, who aimed at overcoming the formalist agenda of the new critics. ${ }^{49}$ Arguing that the structures of literary texts ultimately reveal a deeper sense of an essential American reality characterized by paradox and polarity, Krieger and Pearce, though, as Fluck underlined, merely projected contextualist notions of literary form onto history or social formations (Fluck, "Das ästhetische Vorverständnis" 123-25). To a certain degree this contextualism of early American Studies is reproduced by Stephen Greenblatt's concept of a poetics of culture which circulates social energies. ${ }^{50}$ Rather than engaging in interdisciplinary work, new historical analyses employ terms central to current literary and cultural interpretation for the analysis of legal or scientific discourses without testing, in a consequential manner, how far legal or medical concepts and methods may in turn push readings of literary texts. Ultimately, such practice of interpretation, thus, reaffirms the privileged position of both literary studies and particular, oftentimes 'classic,' literary texts, even if those texts are now seen as complicit, rather than adversarial to dominant ideology (cf. Lenz, "Reconstructing" 31). And even if new historical analyses dispense with synechdochal/metaphoric conceptions of the relation between text and context and embrace the metonymical figure of the chiasmus to delineate discursive exchanges and networks instead-thereby circumventing questions of cultural hierarchy and authorization-they do retain a closural sense of culture. According to Fluck, new historical perspectives, therefore, do not enable recontextualized readings, but lead to decontextualizations ("Die "Amerikanisierung" 234-35, 246). Nor did they mean to inaugurate a methodologically innovative approach. The New Historicism, according to Fluck, was motivated and self-authorized first and foremost by a political self-fashioning of its protagonists, loosely grounded in the work of Foucault, and by a desire to increase the visibility and significance of literary studies by engaging in surprising interpretive performances.

Other critics feel more uncomfortable with the highly fragmented views of historical processes projected by new historical approaches, which resist teleological histories because they force processes of exclusion (see Reichardt, "The New Historicism"). Giving New Historicism credit for most attractive readings of arbitrarily connected cultural material, German scholars find the focus on synchronical analyses, which tends to relegate continuities to the periphery, too exclusive and call, as Ulfried Reichardt ("The New Historicism") and Mackenthun do, ${ }^{51}$ for productive alliances of synchronic and diachronic perspectives. Historian Thomas Bender, keen to relate detailed analyses of social history to a general reassessment of United States history, confronted the preferred pluralism of cultures and critical perspectives characteristic 
for American Studies in the 1980s with his plea for a "new synthesis." ${ }^{2}$ This desire to move beyond pluralism and regain a grip on the 'big picture' may indeed be one way that German American Studies asserts its cultural difference. Hans-Joachim Lang, for instance, detects a "need for synthesis" as the driving force behind Emory Elliott's and Sacvan Bercovitch's comprehensive literary histories (Lang 122-24). Whether we read these projects as an attempt at synthesis or as an act of revision of established canons and periodizations (as which they were explicitly intended) (cf. Elliott, xviii), whether their aim is to 'make whole' rather than 'make new' or 'make over' obviously lies in the eye of the beholder. Likewise, those who censor the desire to balance a new pluralism with new national paradigms-paradigms that meanwhile allow for contingencies and conflict-as an attempt at "pluralistic totalities" or new universalisms may in part be motivated by specific German anxieties (Klähn 427-30). However, apart from cultural sensibilities, the need to retain national paradigms and comprehensive perspectives may simply result from the particular institutional disposition of American Studies in Germany. American Studies will survive only if we violently defend both the specificity of United States cultures and histories and our particular approach to cultural analysis. It is most banal but blatantly evident, especially for those colleagues currently on the job market : As scholars and teachers of American Studies in the German university system, we cannot ride our hobbyhorses but need to be generalists-experts of "the study of American culture, past and present, as a whole" (H.N. Smith).

The scepticism Lenz voiced vis-à-vis "the [...] process of a 'repoliticization' or 'rehistoricization' of American literary and cultural criticism"-a process of reAmericanization of literary and cultural studies after a strong European impact-"and the versions of a premature synthesis" is of a different calibre ("Reconstructing" 23; cf. "Multicultural Critique"). Lenz relentlessly disclosed the ahistoricities of new historical analyses, exposed the new exceptionalism in some work labelled 'historical,' and historicized the historical and political twists and turns, insisting that critical discourse is "a form of social action" and that differences between deconstruction and Marxist dialectics, for instance, should not be obscured. His very particular concern, though, was to underline how little energy has been spent revising "in a serious theoretical manner" the American traditions of critical thought after the new criticism (Lenz, "Reconstructing" 23-24). Lenz himself has spent a relentless amount of his intellectual verve working "toward a 'historical reconstruction' of American Studies," a reconstruction not aimed at a "philosophy" of American Studies, but at resurrecting the "tradition of a radical cultural history that has been at the heart of the early American Studies" ("American Studies-Beyond the Crisis?" 94, 101). Arguing that American critics oftentimes fail to recognize the radical traditions and the subversive potential of American creative and critical discourses, Lenz clearly affirms a cultural difference, which amounts to a difference in both theoretical thought and scholarly practice. Aiming at transcultural dialogues, he finds in feminist criticism, women's and gender studies, African American theory, and new ethnographies a heterogenous field of interdependent cultural forces and models for transdisciplinary work (see "Reconstructing" 32-40, "Ethnographies"). In fact, throughout his work, Lenz dialectically and dialogically as well as pragmatically engaged with and tried to accomodate new and productive theoretical paradigms, in this way, affirming his own difference within the German American Studies 'community.'

7. Returning to Pragmatism, Undoing American Studies? 
He [the American Studies scholar] works, [sic] then in the heritage of Emerson and his

philosophy of self-trust, and in the heritage of William James and his philosophy of pragmatism.

Tremaine McDowell qtd. in O. Hansen 141

In its original form, pragmatism is a philosophical theory about truth. It attempts to undermine the traditional metaphysical quest of philosophy for

a timeless truth that would correspond to the way the world 'really' is. In contrast, pragmatists claim that our thinking is always goal-directed.

Thinking is a problem-solving device. Hence, 'truth' is practice-oriented, situational, provisional, experimental and processual in the sense that it is constantly emerging anew in never-ending processes of adaptation to experience and readjustment to intersubjective encounters. As a consequence, pragmatism can not only account for a plurality of coexisting perspectives; it also provides a philosophical justification of the inevitability of such a plural universe. Thus, pragmatism's goal is not to pursue the elusive, 'impossible' question of philosophical foundations but to offer a method or mode of thinking for making our ideas clear.

Fluck, Introduction ix

I am quoting at length here from Winfried Fluck's introduction to a collection of essays, dedicated to "Pragmatism and Literary Studies," because its first paragraph clearly foregrounds why, in the last decade, (American) philosophy has increasingly informed literary and cultural studies ${ }^{53}$ and why, more particularly, pragmatism has (re-)evolved as a theoretical paradigm for American Studies. ${ }^{54}$ While, on the one hand, formulating a critique of philosophy and its attempt to define absolutes and a priori truths, pragmatism evolves a sense of truth that allows for process and plurality, appropriates the scientific concept of experimentation for the evaluation of individual experiences of the world, and makes this plurality of experience, including aesthetic experience, the basis for novel conceptions of truth. Pragmatism, as developed, in different varieties, in the writings of Emerson, William James, John Dewey, Charles Sanders Peirce, and Hilary Putnam, has insisted that there can be no one formal system of knowledge, since knowledge is processual and mutable; accordingly, if we let our sense of the world be guided by our experience of it, our perspectives on the world will have to continuously shift. In some sense, pragmatist thought has indeed anticipated poststructuralist notions of difference/différance. Accordingly, Fluck acknowledges "striking similarities" (Introduction ix) between pragmatism and poststructuralism. While pragmatism as "one of the major attempts," as Herwig Friedl puts it, "to overcome the tradition of classical Western metaphysics" ("Thinking" 469) accommodates (poststructuralist/postmodernist) pluralities (of subject positions, identity politics, ethnicities, truths etc.), it has at the same time revitalized concepts that poststructuralism appears to negate, first and foremost our sense of subjectivity 
and agency, experience, reality, and truth. In this way, Fluck claims, pragmatism "escapes the recent radical critique of essentialism in Western thought." Whereas poststructuralism has taken the instability of truth, meaning, and self "as evidence for the all-pervasive power effects of linguistic and discursive regimes," "pragmatism holds the promise of describing central aspects of cultural expression such as representation, rhetorical expression, meaning, aesthetic experience, and 'selffashioning' in terms that do not have to ignore the constructive and creative dimensions of these acts" (Introduction ix). To a certain degree, current revisions of pragmatism, thus, reaffirm "the primacy of processes of perception over their object," which Olaf Hansen, in 1973, described as central to the pragmatist paradigm of American Studies (148). ${ }^{55}$ Whereas Hansen's discussion of pragmatist perspectives aimed at disclosing their idealism and ideology, though, current appropriations of pragmatism tend to set themselves up against critiques that appear to be ideologically motivated and against what Hansen labelled "the silent paradigm shift in the humanities," which entailed the transformation of literary into cultural studies (cf. Kulturbegriff und Methode). They "disremember," for instance, that long before the "pragmatist" and "ethical turn" feminist critics insisted on the "authority of experience" and that poststructuralist theory has explicitly acknowledged the interdependence of deconstructive and reconstructive or creative moves, arguing, for instance, as Teresa de Lauretis did in 1987, that the deconstruction of gender is its reconstruction (3).

Prone to forgetting, the tendency to revitalize pragmatist thought at the expense of more explicitly political perspectives or poststructuralist parameters may strike us as odd, occurring right after or synchronic with the so-called historical turn American Studies took in the late 1980s and early 1990s and characterizing even the work of scholars who certainly need not to be told to "always historicize." At the same time "[t]his tendency to brush away history, and to start all over again into a pristinely unknown future," Claviez argues, "is [...] an integral part of both the pragmatic vein within American culture and of Pragmaticism as a philosophical approach" ("Afterword" 332; see also "Pragmatism" and Grenzfälle). Moreover, in recent theoretical debates these acts of forgetting-or outright dismissal-are inextricably linked with acts of remembering. In Fluck's essay "Pragmatism and Aesthetic Experience," for instance, the rereading of Dewey serves to call upon the "Constance school of reception aesthetics" as "one of the few of the so-called 'Continental theories' of the recent theory boom in literary and cultural studies in which the name Dewey functions as an important point of reference" (230). In this way, Fluck, on the one hand, reminds us of those German contributions to continental theory that have been marginalized by dominant poststructuralist paradigms. On the other, this act of remembering goes along with a dismissal of British cultural studies and 'identitycriticism.' Interpreting Dewey's Art as Experience (1934) as the major force behind the "elimination of the hierarchy between high and popular culture and his redefinition of the discipline of English," Fluck acknowledges Dewey as a precursor of the work of Raymond Williams, whose The Long Revolution is partly based upon Dewey's text. In a move analogous to that of Stanley Cavell, who argued that Emerson anticipated modern continental philosophy, Dewey not only becomes the proponent cultural studies avantla-lettre (Fluck, Pragmatism 341, 328-29). Theories of cultural studies also become an American trademark. To be sure : My point here is not to question this observation or the argument it enables, but to challenge its underlying attempt at truth-telling and 
'identity criticism,' replete with the recovery of one's own 'roots' and the reaffirmation of one's own critical position at the expense of other views. Theorizing literary (and American) studies openly reveals itself as a form of identity politics-or "a politics of self-empowerment" (Fluck, "The Humanities" 218) ${ }^{56}$-here (which comes as no surprise, of course).

The most significant intervention into what some critics feel to be a critical impasse created by the dominance of poststructuralist thought is the reempowerment of a subject that in perceiving the world engages in its creation and the revitalization of the pragmaticism or pragmatist semiotics of Peirce. As Susanne Rohr has convincingly argued, Peirce's "pragmatist-semiotics" are of such fundamental importance, because they provide us with an alternative definition of the sign and, as a result, of reality itself ("Pragmaticism" 294). For Peirce reality is "a "product of sign processes" or "an "interpretive outcome," and therefore constantly being re-negotiated (Rohr, "The World" 96). Realigning subject, cultural artifact, and world, Peirce's work targets a question that has indeed been central to all "great moments in lit-crit" and most crucial to American Studies. How can we explain the relationship between text and world, Rohr asks, acknowledging, on the one hand, how problematic notions of mimesis in fact are while, on the other, allowing for the fact "that fictional realities have something to do with their historical context, after all" ("Pragmaticism" 293)? ${ }^{57}$ Now poststructuralism certainly provided one reply to this question. Focusing on how discourses create our sense of the world, our concepts of reality and truth, poststructuralist thought has capitalized on the production and reproduction of meaning and cultural imaginaries. Focusing on our acts of reading and interpretation, pragmatism, by contrast, offers a reply that foregrounds the position of the (individual) subject in these processes of constituting the world, his or her power to add an individual to a cultural narrative, and the possibilities of intersubjectivity (Fluck, "Pragmatism" 241). Rather than judging which answer is more to the point, though, we may simply want to register which reply becomes prominent at what time.

Rohr's own reply has been to propose "a new pragmatist, i.e. subject-oriented semiotic approach to literature and other forms of representation" ("Pragmaticism" 293). Intent to speak of the relation between literary text and world without merely falling back into pre-deconstructionist positions, she proposes a literary theory that reintegrates previously discarded concepts such as meaning and mimesis while maintaining essential deconstructionist insights concerning the openness, decenteredness and infinity of discourse, the cultural constructedness of the self, and the plurality of sign processes. Exploring Peirce's notion of human cognition and employing his pragmaticism for a rereading of American literature, from classic American realism to contemporary neo-realism, Rohr has done most significant groundwork and has indeed found "new critical options" for literary studies (see Die Schönheit des Findens; Die Wahrheit der Täuschung; "Pragmaticism" 294); in fact, Katrin Amian already speaks of a "Rohrian approach" (see "Pynchon"). At the same time Rohr frames her argument by pinpointing the presumed inadequacies of a whole series of other theoretical paradigms, including "classical structuralist, but also post-structuralist, deconstructivist, New Historicist, race, class and gender theories." Saussurian "semiotic theory," she claims, "has monopolized theoretical thinking in literary and cultural studies for an entire century, operating with premises whose implications are now entirely predictable" and evolving "a dyadic model [which] cannot but force all arguments into figures of binary opposition" ("Pragmaticism" 293). And even where 
concepts of decidedly non- binary character (such as hybridity) are introduced, none of these theories, she claims, "have critically reflected their semiotic foundations." These claims are, of course, quite comprehensive (even if we set aside the fact that Derrida, Irigaray, Butler, Gates, Homi Bhabha, Arnold Krupat, Lisa Lowe among others-and who else could be referred to in this context?-have certainly reflected the semiotic foundations of their theories, though this may not have been marked first priority on their critical agenda). They tend to operate with binary oppositions and antagonisms, conflict with pragmatist philosophy itself, fail to acknowledge that "race, class and gender theories" have come a long way, and to my mind misread poststructuralism's renegotiations of established notions of subjectivity as a process of "emptying the position of the subject" (Rohr, "Pragmaticism" 294).

Thus while acknowledging the cross-routes between pragmatism and poststructuralism, current pragmaticist approaches to American literature do not travel these routes all that far. Judith Butler, for instance, has always acknowledged that neither are subject positions and views of the world imposed or inscribed upon the individual nor do embodied selves pre-exist the cultural conventions. ${ }^{58}$ Moreover, throughout the 1990s, protagonists of the poststructuralist debate have interrogated the preconditions for an ethically and politically responsible agency (cf. Butler, The Psychic Life). As Butler's reflections on subjectivity and agency return to Hegel, they become part of an analytic reexamination of some of the fundamental positions in modern continental thought currently underway and enter, from a distinct direction, a field where, as Mike Sandbothe points out, previously unacknowledged or underappreciated pragmatic elements in thinkers like Kant, Hegel, Nietzsche, Heidegger, and Wittgenstein are being explored. At the same time for Butler, the agent remains an arena of ambivalence, the effect of powers that precede him or her as well as the possibility of a radically conditioned form of agency ${ }^{59}$ Current uses of pragmatism, by contrast, may allow for the processual nature of reality and subjectivity, yet retain the sense of a consistent subject, of an individual who can make his or her ideas clear. Whereas Butler and Slavoj Žižek negotiate conceptions of subjectivity which account for contingencies and incoherencies, for the interdependence between discourses of power and the topography of the psyche, pragmatism tends to bracket psychoanalytical insights into subject constitution, thereby echoing a general discomfort American cultures has felt vis-à-vis psychoanalysis. Pragmatism remains unconcerned by intrusions of the Lacanian real, and, as Claviez argues, "naïve[ly] neglect[s] the problem of power-especially as it adheres in the subject-object-relation" ("Pragmatism" 359). Intended or not, the revitalization of pragmatism catalyzes the renaissance of an (Emersonian) American individual, ideas of progress, and the belief that aesthetic experience is the motor of both individual and cultural progress. (Kristeva made similar claims for "poetic practice." ${ }^{60}$ ) Whereas poststructuralism emphasizes performativity, pragmaticism capitalizes on the "actor" or agent that fiction and art allow us to "become" (Fluck, "Pragmatism" 341). Experience of art or other aesthetic artifacts thus transforms into a future-oriented politics of change. Whereas the division between "social facts"/science and "aesthetic values"/humanities constituted a fundamental dualism in the early debates on American Studies methods (O. Hansen 144), we are now at a point where, after having reassessed facts and values, we recover "aesthetic experience" as a way of knowing the world, of bridging the gap between self and other (cf. Claviez, "Pragmatism" 353), of articulating "otherwise 
inexpressible dimensions of the self" (Fluck, "Pragmatism" 341), and of reconceiving intersubjectivity as consensual rather than conflictual.

To my mind, by contrast, the many cross-routes as well as the specific concerns of current theories of American Studies rather hint that we might fare best if we resist dividing pragmatism, poststructuralism, and politically informed cultural studies into separate camps where they do not belong. In the context of his "search for ecological genealogies in American culture," Claviez, for instance, recommends that we reengage the methodological assumptions made by (early and later) American Studies (Marx, Nash Smith, Bercovitch, Lawrence Buell), reconsider critical theory (here Adorno), and realign American and European philosophy in order to arrive at "an alternative" to pragmatism's denial of hierarchies of power and "a post-Romantic assessment of a possible marriage between self and world" ("Pragmatism" 359, 378). Likewise, it might be more pragmatic to consult, in matters that pragmatism relegates to the periphery, those theories that are really good on peripheral matters. What about, for instance, the fact that aesthetic experience can mean many things to many individuals? Pragmatism -especially if employed as a theory of interpreting literary texts-reempowers the reader. Who is that reader, though, and what is he or she reading? Most likely, he or she is a literary critic. So what does the critic read? So far, he or she is primarily engaged in a revision of 'classic' American texts. (In fact, pragmatism's most obvious effect on German American Studies, at this point in time, has been to raise the status of and in fact Americanize the study of aesthetics and of canonical literature.) What about the reader who resists being empowered, who is there simply for the ride (see Eco 321)? What about a reader/listener/viewer who, as Christoph Ribbat puts it in this volume, does not want to hide his or her love forever? And what about the reader who prefers not to read and tunes in or interactively engages computer games?

Bringing these questions to bear on the new pragmatist paradigm, we may avoid returning to presuppositions of an early American Studies agenda and to becoming the kind of practitioner of American Studies whom Olaf Hansen considered "more a construction of a history of ideas than a concrete individual motivated by social contexts" (141). ${ }^{61}$ Just as shifts in theoretical perspectives have opened new dimensions of paradigmatic postmodernist fiction, foregrounding that postmodern texts, far from exhausting themselves in "language games," raise moral and ethical questions as well (see Hoffmann and Hornung), a reemphasis of aesthetics (see Ickstadt, "Toward a Pluralist Aesthetics") can do much good for readings of "ethnic literatures" (see Schiller), which more often than not ignore matters of form. Accordingly, the full potential of pragmatism for literary studies will come to the fore when it engages texts from the periphery or is employed by 'peripheral' readers. However, since there is no "body of knowledge called pragmatism" (Fluck, Introduction x) only a plurality of (neo-)pragmatisms, pragmatism can provide neither theory nor method for American Studies, even though it is noteworthy that the term method is being reintroduced in this context. ${ }^{62}$ Rather, in its final consequence, pragmatism undoes the very project of trying to circumscribe what American Studies actually busies itself with. At the same time, despite the fact that pragmatist approaches to American literature dissociate themselves from ideologically motivated cultural analyses, they tend to repeat these analyses'-explicit or implicit, and somewhat utopian-promises of (or aspirations toward) difference without hierarchy. Thereby, they come quite close to what has been labelled the core or heart of the American Studies agenda, "the pursuit of what constitutes democratic culture (Kessler-Harris qtd. in Ickstadt, "Americanization" 9), of 
an America that is "as yet unrealized" (Ickstadt, "Americanization" 155). Theorizing work on media other than literature evolving within German American Studies also remains yet unrealized; work, which capitalizes on American cultural productions, yet, does not necessarily conceptualize its disciplinary leanings. This may perhaps be an arena where pragmatism's appeal to interdisciplinarity may come into play more prominently.

8. Theory as Practice, Practice as Theory, or : Futures for American Studies

In concluding, let me briefly return to the essay collection, edited by Fluck and Claviez in 2003, concerned with theories of American culture and/as theories of American Studies. Its significance is not so much due to the theories it discusses; in fact, there is much less of such debate than one might perhaps expect. Significant is how this deficit is sanctioned : all work in American Studies, the editors emphasize, is "grounded in a set of underlying constitutive views of American culture" and relies on "often tacit assumptions" which may not be systematically developed as theories, yet "imply generalizations about 'America' or the meaning of American history that have a systematic dimension, no matter whether this dimension is fully worked out or not" (Fluck and Claviez, Introduction ix). Aimed at making the implicit assumptions of our interpretations of American society and culture topical (xi), ${ }^{63}$ the editors' agenda acknowledges how dramatically our conceptions of theory have changed. Whereas in the 1970s, explorations of methods and theories were legitimized by the practice they enable, we now do theory when engaging each others' critical practice. And this in itself is an effect of the 'rise of theory' in 1980s literary and cultural studies.

At the same time, the practice of American Studies in Germany is by no means limited to literary studies-and this is, after all, at least partly an effect of (post-) structuralism and (Saussurian) semiotics. Work in the realm of popular culture and the new mediaincluding visual cultures (photography, film, video, multimedia), new technologies (hypertext, CD-ROM, computer and video games), the history of the sciences, ecocriticism, performance studies, explorations of intermediality and reconceptualizations of time and space ${ }^{64}$-have suggested that we have meanwhile made a whole series of turns, turning out to be quite transdisciplinary after all. Therefore, it is indeed timely to note, as the initiators of the DFG-network on "The Futures of (European) American Studies" do, that most of the debates on theories and futures of American Studies easily do without figuring in explorations of popular culture and the new media. In fact, as Katrin Amian, Michael Butter, Elisabeth SchäferWünsche, Ingrid Thaler, and their collaborators claim, despite their inclusion of cinematic discourse, "current theories of American Studies are dominated by the paradigm of print." ${ }^{55}$ Addressing this Medienvergessenheit and extending our theoretical debates to theories of other media, they convincingly argue, allows to engage the interdependencies between new forms of cultural production and new political and economic challenges, including organized terrorism and the new American front(iers), home and abroad. Moreover, the practice of theorizing new media also adds another dimension to current attempts to internationalize American Studies. After all, the internationalization of our pursuits is as much the result of the globalization of certain technologies as it is indebted to the singular efforts of particular individuals located in particular places. Thus, if some of us redefine American Studies as media studies, ${ }^{66}$ we necessarily challenge the authority of certain texts and readers, by embracing a different, a processural sense of (inter)subjectivity instead. 
In a most general sense, such interrogation of critical practices for their conceptual significance clearly foregrounds that theory is not-and theories of American Studies have never been-a one-way street. Theory opens perspectives on the world while the readings of the world they enable hopefully, ideally, reflect back upon and readjust our perspectives. Readings of the world and its media, in turn, evolve paradigms which may challenge and extend our established ways of approaching cultural practices. Theorizing thus remains a highly dialectical matter. And as the transdisciplinary work of Žižek brings to light, moving between Hegel and Lacan, between the scenes of Hitchcock's movies, the scenarios staged at Abu Ghraib, and the prospects of biogenetic intervention, it not only affirms theory as both practice and politics. It also foregrounds that dialectics does not necessarily mean thesis, antithesis, synthesis. Nowadays more often than not dialectics spells thesis, antithesis, contradiction. Thus, if there are futures for American Studies it seems that neither centrifugal pluralisms, as envisioned in Whitehead's "Lit-O-Rama," nor barriers between seemingly opposed camps will do. Because clearly separated camps often turn out contradictions too hard to acknowledge, let alone bear; because we are all in one boat (even if ours may not be the French feminist's love boat) and, to add another truism, because the supposed others are always parts of our selves. To call on Žižek in this context, therefore, is not to suggest that the most interesting work on American culture is being done "outside of American Studies" ${ }^{67}$ or that "[t]o open up outside perspectives," as Claviez claims, "[...] allow[s] for a distance" that American American Studies may lack ("Whose 'American' Century?" 258). It is to emphasize that distance, like clarity, is hard to be had. Žižek insists that we can do neither without a concept of the subject that acknowledges his or her fundamental instability and the (Lacanian) real as a fundamental part of the human condition and thus all cultural phenomena; nor can we abolish ethical thinking. Like Rorty, Žižek is highly critical of "[t]he multitude of particular ethics that spread nowadays (the ethics of ecology, medical ethics ...)," not because they tend to reinscribe social and economic hierarchies, though, but because they hamper what he considers "the true ethic, the ethics of an act whose status is that of the real" (204).

The major contradiction that we need to bear is that, yes, the meaning of America has been deeply compromised since American Studies started to reflect its methods. And yet if we want to outweigh the "continuing process of self-deconstruction," we should, as Ickstadt keeps insisting ("Americanization" 156), accept the name American Studies as the boundary, first of all perhaps because under certain conditions the national framework is not a boundary but an open vista. If we frame the transdisciplinary study of popular and visual cultures, for instance, by way of national perspectives, there may be many new methodological and theoretical challenges and more 'great moments in Amst' ahead. In fact, by rendering the "great moments in lit-crit" by way of visuals, the Village Voice makes exactly this point. At the risk of repeating myself : wherever we may turn next-American Studies is dead. Long live American Studies! 


\section{BIBLIOGRAPHIE}

Works Cited

Adorno, Theodor. "The Stars Down to Earth : The Los Angeles Times Astrology Column. A Study in Secondary Superstition." Jahrbuch für Amerikastudien 2 (1957) : 19-88.

Amian, Katrin. "Pynchon, Peirce und die amerikanische Postmoderne : Gedanken zu einer Neupositionierung jenseits des Poststrukturalismus." Jenseits des Poststrukturalismus? : Eine Sondierung. Ed. Marcel Lepper, Steffen Siegel, and Sophie Wennerscheid. Frankfurt/M. : Lang, 2005. 77-104.

Bach, Gerhard, Sabine Bröck, and Ulf Schulenberg, eds. Americanization-Globalization-Education. Heidelberg : Winter, 2003.

Baßler, Moritz. "Einleitung : New Historicism-Literaturgeschichte als Poetik der Kultur." New Historicism : Literaturgeschichte als Poetik der Kultur. Ed. Moritz Baßler. Frankfurt/M. : Fischer, 1995. 7-28.

---. ed. New Historicism : Literaturgeschichte als Poetik der Kultur. Frankfurt/M. : Fischer, 1995.

Bender, Thomas. "Wholes and Parts : The Need for Synthesis in American History." Reconstructing American Literary and Historical Studies. Ed. Günter H. Lenz, Hartmut Keil, and Sabine Bröck-Sallah. Frankfurt/M. : Campus, 1990. 51-73.

Berkhofer, Robert F. “A New Context for New American Studies.” American Quarterly 41.4 (1989) : 588-613.

---. "Problems of a New American Studies." America Seen from the Outside : Topics, Models, and Achievements of American Studies in the Federal Republic of Germany. Ed. Brigitte Georgi-Findlay and Heinz Ickstadt. Berlin : Freie Universität Berlin, 1990. 148-64.

Berressem, Hanjo, ed. Chaos-Control / Complexity: Chaos Theory and the Human Sciences. Spec. issue of Amerikastudien / American Studies 45.1 (2000).

Brook, Thomas. New Historicism and Other Old-Fashioned Topics. Princeton : Princeton UP, 1991.

Butler, Judith. Gender Trouble : Feminism and the Subversion of Identity. New York : Routledge, 1999.

---. "Performative Acts and Gender Constitution : An Essay in Phenomenology and Feminist Theory." Performing Feminisms : Feminist Critical Theory and Theory. Ed. Sue-Ellen Case. Baltimore : Johns Hopkins UP, 1990. 270-82.

---. Die Psyche der Macht : Das Subjekt der Unterwerfung. Frankfurt : Suhrkamp, 2001.

---. The Psychic Life of Power : Theories of Subjection. Stanford : Stanford UP, 1997.

Christadler, Martin, and Günter H. Lenz, eds. Amerikastudien-Theorie, Geschichte, interpretatorische Praxis. Spec. issue of Amerikastudien / American Studies (1977).

---. Vorwort. Amerikastudien-Theorie, Geschichte, interpretatorische Praxis. Ed. Martin Christadler and Günter H. Lenz. Spec. issue of Amerikastudien / American Studies (1977) : 5-6.

Claviez, Thomas. "Afterword : American Studies-The State of Affairs and the Affairs of the State." Theories of American Culture, Theories of American Studies. Ed. Winfried Fluck and Thomas Claviez. Tübingen : Narr, 2003. 325-41.

---. Grenzfälle : Mythos-Ideologie-American Studies. Trier : WVT, 1998. 
---. "Pragmatism, Critical Theory, and the Search for Ecological Genealogies in American Culture." Pragmatism and Literary Studies. Ed. Winfried Fluck. Tübingen : Narr, 1999. 343-80.

---. “Whose 'American' Century? Whose ‘American' Studies? Or : What Indeed Is in a Name?" Millenial Perspectives : Lifeworlds and Utopias. Ed. Brigitte Georgi-Findlay and Hans-Ulrich Mohr. Heidelberg : Winter, 2003. 249-61.

Derrida, Jacques. "Structure, Sign, and Play in the Discourse of the Human Sciences." Modern Criticism and Theory : A Reader. Ed. David Lodge. London : Longman, 1988. 107-23.

Dickstein, Morris, ed. The Revival of Pragmatism : New Essays on Social Thought, Law and Culture. Durham : Duke UP, 1998.

Eco, Umberto. "Serialität im Universum der Kunst und der Massenmedien." Im Labyrinth der Vernunft. Ed. Michael Franz and Stefan Richter. Leipzig : Reclam, 1995. 301-24.

Elliott, Emory, ed. Columbia Literary History of the United States. New York : Columbia UP, 1988.

Fishkin, Shelley Fisher. "Crossroads of Cultures : The Transnational Turn in American StudiesPresidential Address to the American Studies Association, November 12, 2004." American Quarterly 57.1 (2005) : 17-57.

Fluck, Winfried, and Thomas Claviez. Introduction. Theories of American Culture, Theories of American Studies. Ed. Winfried Fluck and Thomas Claviez. Tübingen : Narr, 2003. iv-xii.

Fluck, Winfried, ed. "Das ästhetische Vorverständnis der American Studies.” Jahrbuch für Amerikastudien 18 (1973) : 110-29.

---. “The ‘Americanization' of History in New Historicism.” Monatshefte 84.2 (1992) : 220-28.

---. “Die ‘Amerikanisierung' der Geschichte im New Historicism.” New Historicism :

Literaturgeschichte als Poetik der Kultur. Ed. Moritz Baßler. Frankfurt/ M. : Fischer, 1995. 229-50.

---. The Historical and Political Turn in Literary Studies. Tübingen : Narr, 1995.

---. "The Humanities in the Age of Expressive Individualism and Cultural Radicalism." The Futures of American Studies. Ed. Donald E. Pease and Robyn Wiegman. Durham, NC : Duke UP, 2002.

211-30.

---. Introduction. Pragmatism and Literary Studies. Ed. Winfried Fluck. Tübingen : Narr, 1999. ix-xii. ---. Das kulturelle Imaginäre : Funktionsgeschichte des amerikanischen Romans, 1790-1900. München : Fink, 1992.

---. "Pragmatism and Aesthetic Experience." Theories of American Culture, Theories of American Studies. Ed. Winfried Fluck and Thomas Claviez. Tübingen : Narr, 2003. 227-42.

---. "The Role of the Reader and the Changing Functions of Literature : Reception Aesthetics, Literary Anthropology, Funktionsgeschichte." European Journal of English Studies 6 (2002) : 253-71.

---. Theorien amerikanischer Literatur. Konstanz : Universitätsverlag Konstanz, 1987.

Freese, Peter, and Charles B. Harris, eds. Science, Technology, and the Humanities in Recent American Fiction. Essen : Blaue Eule, 2003.

Friedl, Herwig. "Art and Culture as Emerging Events : Getrude Stein, Pragmatism, and Process Philosophy." Emerging Structures in Interdisciplinary Perspective. Ed. Rudi Keller and Karl Menges. Tübingen : Francke, 1997. 43-64.

---. "Global Aspects of American Pragmatist Thinking : William James and Kitaro on the Purity of Experience." Amerikastudien / American Studies 46.2 (2001) : 178-205. 
---. “Thinking America : Emerson and Dewey." Negotiations of America's National Identity. Ed. Roland Hagenbüchle, Joseph Raab, and Marietta Messmer. Vol. 2. Tübingen : Stauffenburg, 2000. 131-57.

---. "Thinking in Search of a Language : Pragmatism and the Muted Middle Voice." Amerikastudien / American Studies 47.4 (2002) : 469-90.

Galinsky, Hans. “American Studies in Germany.” American Studies in Transition. Ed. Marshall W. Fishwick. Philadelphia : U of Pennsylvania P, 1964. 232-52.

Gassert, Philipp. Amerika im Dritten Reich : Ideologie, Volksmeinung und Propaganda, 1933-1945. Stuttgart : Steiner, 1997.

Gernalzick, Nadja. "Border Bending : Deconstruction and the Postmodern with Judith Butler and Her Reception in Germany." The Sixties Revisited : Culture, Society, Politics. Ed. Jürgen Heideking, Jürgen Helbig, and Anke Ortlepp. Heidelberg : Winter, 2001. 381-95.

Goodman, Russell B., ed. Pragmatism : a Contemporary Reader. London : Routledge, 1995.

Grabbe, Hans-Jürgen. “50 Jahre Deutsche Gesellschaft für Amerikastudien.” Amerikastudien / American Studies 48.2 (2003) : 159-84.

Haas, Renate. "Die Geschichte der Anglistik und Amerikanistik an deutschen Universitäten." Handbuch : Englisch als Fremdsprache. Ed. Rüdiger Ahrens, Wolf-Dietrich Bald, and Werner Hullen. Berlin : Schmidt, 1995. 481-86.

Hansen, Klaus P. Kulturbegriff und Methode : Der stille Paradigmenwechsel in den Geisteswissenschaften. Tübingen : Narr, 1993.

Hansen, Olaf. “American Studies : Zur Theorie und Geschichte der Disziplin." Jahrbuch für Amerikastudien 18 (1973) : 130-72.

Hark, Sabine. "Disputed Territory : Feminist Studies in Germany and its Queer Discontents." Amerikastudien / American Studies 46.1 (2001) : 87-103.

Haselstein, Ulla. "Stephen Greenblatt's Concept of a Symbolic Economy." The Historical and Political Turn in Literary Studies. Ed. Winfried Fluck. Tübingen : Narr, 1995. 347-70.

Haverkamp, Anselm, ed. Deconstruction is/in America : A New Sense of the Political. New York : New York UP, 1995.

Hebel, Udo J. "Der amerikanische New Historicism der achtziger Jahre : Bestandsaufnahme einer neuen Orthodoxie kulturwissenschaftlicher Literaturinterpretation." Amerikastudien / American Studies 37 (1992) : 325-47.

Heyden, Ulrich van der. "Die Native American Studies im System der Amerikanistik der DDR." Amerikanistik in der DDR : Geschichte-Analyse-Zeitzeugenberichte. Ed. Rainer Schnoor. Berlin : trafo, 1999. 123-51.

Hoenisch, "Zum Begriff der Tradition in der Amerikanistik der DDR.” Amerikastudien-Theorie, Geschichte, interpretatorische Praxis. Ed. Martin Christadler and Günter H. Lenz. Spec. issue of Amerikastudien / American Studies (1977) : 104-127.

Hof, Renate. "Einleitung : Feministische Wissenschaft : A New Feminine Mystique?" Amerikastudien / American Studies 33.2 (1988) : 135-48.

---. "Writing Women into (Literary) History : Toward a Poetics of Gender?" Reconstructing American Literary and Historical Studies. Ed. Günter H. Lenz, Hartmut Keil, and Sabine Bröck-Sallah. Frankfurt/M. : Campus, 1990. 211-24. 
Hoffmann, Gerhard, and Alfred Hornung, eds. Ethics and Aesthetics : The Moral Turn of Postmodernism. Heidelberg : Winter, 1996.

Hornung, Alfred. “American Autobiographies and Autobiography Criticism : Review Essay." Amerikastudien / American Studies 35.3 (1990) : 371-407.

---. “Transnational American Studies : Response to the Presidential Address.” American Quarterly $57.1(2005): 67-73$.

Huyssen, Andreas. "Mapping the Postmodern." Crisis of Modernity: Recent Critical Theories of Culture and Society in the United States and West Germany. Ed. Günter H. Lenz and Kurt L. Shell. Frankfurt/ M. : Campus, 1986. 253-99.

Ickstadt, Heinz. “Americanization, Anti-Americanism, and American Studies.” Over (T)Here : Transatlantic Essays in Honor of Rob Kroes. Ed. Kate Delaney and Ruud Janssens. Amsterdam : VU UP, 2005. $148-60$

---. “American Studies in an Age of Globalization.” American Quarterly 54.4 (2002) : 543-62.

---. Der amerikanische Roman im 20. Jahrhundert : Transformation des Mimetischen. Darmstadt : Wissenschaftliche Buchgesellschaft, 1998.

---. "Toward a Pluralist Aesthetics." Aesthetics in a Multicultural Age. Ed. Emory Elliott et al. Cambridge : Oxford UP, 2002. 79-104.

Irmscher, Christoph, and Sabine Sielke, eds. Theories in Practice : Recent Approaches to American Studies in Germany. Spec. issue of Amerikastudien / American Studies 39.4 (1994).

Isernhagen, Hartwig. “'American Studies' and 'New Literatures in English' : (Literary-)Historical Paradigms in Conflict." Reconstructing American Literary and Historical Studies. Ed. Günter H. Lenz, Hartmut Keil, and Sabine Bröck- Sallah. Frankfurt/M. : Campus, 1990. 145-68.

---. "Postmodern (Dis)continuities, Or : The Americanization of History and the Stubbornness of Interculturality." American Studies in Germany : European Contexts and Intercultural Relations. Ed. Günter H. Lenz and Klaus J. Milich. Frankfurt/M. : Campus, 1995. 131-46.

---. "Roles of Native American Texts in Intercultural Understanding Between the U.S.A. and Germany : Hegemony, and Questions of Legitimacy and Authenticity." Perceptions and Misperceptions : The United States and Germany. Studies in Intercultural Understanding. Ed. Lothar Bredella and Dietmar Haack. Tübingen : Narr, 1988. 79-90.

Keitel, Evelyne. "Weiblichkeit und Poststrukturalismus : Perspektiven einer feministischen Literaturwissenschaft.” Amerikastudien / American Studies 33.2 (1988) : 149-66.

Klähn, Bernd. "From Entropy to Chaos-Theories : Thermodynamic Models of Historical Evolution in the Novels of Thomas Pynchon and Robert Coover." Reconstructing American Literary and Historical Studies. Ed. Günter H. Lenz, Hartmut Keil, and Sabine Bröck-Sallah. Frankfurt/M. : Campus, 1990. 418-31.

Koenen, Anne, ed. Geschlechterdifferenz und Amerikastudien in Deutschland : Analysen und Interpretationen. Leipzig : Leipziger Universitätsverlag, 1999.

Krieger, Murray. The New Apologists for Poetry. Bloomington : Indiana UP, 1963.

Kroes, Rob. "National American Studies in Europe, Transnational American Studies in America?" American Studies in Germany. Ed. Günter H. Lenz and Klaus J. Milich. Frankfurt/M. : Campus, 1995. $147-58$.

Kuhn, Thomas. The Structure of Scientific Revolutions. Chicago : Chicago UP, 1962. 
Kühnel, Walter. “Amerikanische Konsumwerbung : Erscheinungsformen und Wirkungsmöglichkeiten.” Amerikastudien-Theorie, Geschichte, interpretatorische Praxis. Ed. Martin Christadler and Günter H. Lenz. Spec. issue of Amerikastudien / American Studies (1977) : 128-60.

Lang, Hans-Joachim. "From the Old Cambridge History of American Literature to the New Columbia Literary History of the United States." Reconstructing American Literary and Historical Studies. Ed. Günter H. Lenz, Hartmut Keil, and Sabine Bröck-Sallah. Frankfurt/M. : Campus, 1990. $110-27$.

Lauretis, Teresa de. Technologies of Gender : Essays on Theory, Film, and Fiction. Bloomington : Indiana UP, 1987.

Lauter, Paul. "Race and Gender in the Shaping of the American Literary Canon : A Case Study from the Twenties." Feminist Studies 9.3 (1983) : 435-63.

Lehmkuhl, Ursula. “The Historical Values and Historiographic Significance of Jane Addams' Autobiographies Twenty Years at Hull-House and Second Twenty Years at Hull House." Reconstructing American Literary and Historical Studies. Ed. Günter H. Lenz, Hartmut Keil, and Sabine Bröck-Sallah. Frankfurt/M. : Campus, 1990. 285-97.

Lenz, Günter H., and Heinz Ickstadt. "After Poststructuralism and Deconstruction : A New American Exceptionalism?" Affirmation and Negation in Contemporary American Culture. Ed. Gerhard Hoffmann and Alfred Hornung. Heidelberg : Winter, 1994. 177-94.

Lenz, Günter H., Hartmut Keil, and Sabine Bröck-Sallah, eds. Introduction. Reconstructing American Literary and Historical Studies. Ed. Günter H. Lenz, Hartmut Keil, and Sabine Bröck-Sallah.

Frankfurt/M. : Campus, 1990. 9-11.

---. Reconstructing American Literary and Historical Studies. Frankfurt/M. : Campus, 1990.

Lenz, Günter H., and Klaus J. Milich, eds. Introduction. American Studies in Germany. Ed. Günter H. Lenz and Klaus J. Milich. Frankfurt/M. : Campus, 1995. 9-25.

---. American Studies in Germany. Frankfurt/M. : Campus, 1995.

Lenz, Günter H. "American Studies and the Radical Tradition : From the 1930s to the 1960s." Prospects 12 (1987) : 21-58.

---. "American Studies-Beyond the Crisis? Recent Redefinitions, and the Meaning of Theory, History, and Practical Criticism.” Prospects 7 (1982) : 53-113.

---. “American Studies-Wissenschaftskritik und Wissenschaftsgeschichte : Bemerkungen zur neueren Theoriediskussion um die American Studies in den USA." Amerikastudien-Theorie, Geschichte, interpretatorische Praxis. Ed. Martin Christadler and Günter H. Lenz. Spec. issue of Amerikastudien / American Studies (1977) : 29-103.

---. “'Ethnographies' : American Culture Studies and Postmodern Culture Studies.” Prospects 16 (1991) : 1-40.

---. "Multicultural Critique and the New American Studies." Multiculturalism and the Canon of American Culture. Ed. Hans Bak. Amsterdam : VU UP, 1993. 27-56.

---. "Probleme einer Didaktik der Amerikastudien : American Studies-AmerikastudienLandeskunde." Die USA in Unterricht und Forschung. Ed. Lothar Bredella. Bochum : Kamp, 1984. 22-39.

---. "Reconstructing American Literary Studies : History, Difference, and Synthesis." Reconstructing American Literary and Historical Studies. Ed. Günter H. Lenz, Hartmut Keil, and Sabine Bröck-Sallah. Frankfurt/M. : Campus, 1990. 21-50. 
---. "Toward a Dialogics of International American Culture Studies : Transnationality, Border Discourses, and Public Culture(s)." Amerikastudien / American Studies 44.1 (1999) : 5-23.

---. "Transnational American Studies : Conceptualizing Multicultural Identities and Communities -Some Notes." Fremde Texte Verstehen : Festschrift für Lothar Bredella. Ed. Herbert Christ and Michael K. Leguthke. Tübingen : Narr, 1996. 191-202.

Lutz, Hartmut. "Native American Studies in Europe : Caught between 'Indianthusiasm' and Scholarship." ZENAF Arbeits- und Forschungsberichte 1 (2000) : 13-25.

Mackenthun, Gesa. "Vom Nutzen und Nachteil historischer Anfänge in den Early American Studies." Amerikastudien / American Studies 38.2 (1993) : 223-36.

Marx, Leo. “American Studies-A Defense of an Unscientific Method.” New Literary History 1 (1969) : 75-90.

---. "On Recovering the 'Ur'Theory of American Studies." Theories of American Culture, Theories of American Studies. Ed. Winfried Fluck and Thomas Claviez. Tübingen : Narr, 2003. 3-17.

Mayer, Ruth. Artificial Africas : Colonial Images in the Times of Globalization. Dartmouth : UP of New England, 2002.

---. "Science Studies-Global Studies? Kulturwissenschaften im Wandel." Kulturwissenschaftliche Perspektiven in der Nordamerika-Forschung. Ed. Friedrich Jaeger. Tübingen : Stauffenberg, 2002. 63-80.

Menand, Louis, ed. Pragmatism : A Reader. New York : Vintage, 1997.

Milich, Klaus J. “Der Streit um ‘die zwei Kulturen' : Charles Percy Snow and Matthew Arnold.” Die frühe Postmoderne : Geschichte eines europäisch-amerikanischen Kulturkonflikts. Ed. Klaus J. Milich. Frankfurt/M. : Campus, 1998. 59-71.

Miller, Nancy. "Changing the Subject : Authorship, Writing, and the Reader." Feminist Studies/ Critical Studies. Ed. Teresa de Lauretis. New York : Norton, 1982. 1-26.

Neubauer, Paul. Die Rezeption der US-amerikanischen Literatur der Postmoderne im deutschsprachigen Raum. Frankfurt/M. : Lang, 1991.

Newfield, Christopher. Ivy and Industry : Business and the Making of the American University, 1880-1980. London : Duke UP, 2003.

Nolte, Paul. Generation Reform : Jenseits der blockierten Republik. München : Beck, 2004.

Nussbaum, Martha. Love's Knowledge : Essays on Philosophy and Literature. New York : Oxford UP, 1990 .

---. Poetic Justice : The Literary Imagination and Public Life. Boston : Beacon, 1995.

Porter, Carolyn. "What We Know That We Don't Know : Remapping American Literary Studies." American Literary History 6.3 (1994) : 467-526.

Radway, Janice. “'What's in a Name?' : Presidential Address to the American Studies Association, 20 November, 1998." American Quarterly 51.1 (1999) : 1-32.

Reichardt, Ulfried, and Sabine Sielke, eds. Engendering Manhood. Spec. issue of Amerikastudien / American Studies 43.4 (1998).

Reichardt, Ulfried. Innenansichten der Postmoderne : Zur Dichtung John Ashberys, A.R. Ammons', Denise Levertovs und Adrienne Richs. Würzburg : Königshausen, 1991. 
---. “The New Historicism : History as Process and Narratives of Emergence." Reconstructing American Literary and Historical Studies. Ed. Günter H. Lenz, Hartmut Keil, and Sabine Bröck-Sallah. Frankfurt/M. : Campus, 1990. 68-76.

---. "Poststrukturalismus und der New Historicism : Geschichte(n) und Pluralität." Arbeiten aus der Anglistik und Amerikanistik 16.2 (1991) : 205-23.

Reinhard, Rebekka. Gegen den philosophischen Fundamentalismus : Postanalytische und dekonstruktivistische Perspektiven. München : Fink, 2003.

Riese, Utz. "Über den Umgang mit dem Diskurs von Poststrukturalismus und Postmoderne in der DDR." Amerikanistik in der DDR : Geschichte-Analysen-Zeitzeugenberichte. Ed. Rainer Schnoor. Berlin : trafo, 1999. 189-209.

Rohr, Susanne. "'Playing Nazis,' 'Mirroring Evil' : Die Amerikanisierung des Holocaust und neue Formen seiner Repräsentation.” Amerikastudien / American Studies 47.4 (2002) : 539-53.

---. "Pragmaticism-A New Approach to Literary and Cultural Analysis." Theories of American Culture, Theories of American Studies. Ed. Winfried Fluck and Thomas Claviez. Tübingen : Narr, 2003. 293-305.

---. Die Schönheit des Findens : Die Binnenstruktur menschlichen Verstehens nach Charles S. Peirce: Abduktionslogik und Kreativität. Stuttgart : M \& P, 1993.

---. Die Wahrheit der Täuschung : Wirklichkeitskonstitution im amerikanischen Roman 1889-1989. München : Fink, 2004.

---. “The World as 'Ordinary Miracle' in William Dean Howells's A Hazard of New Fortunes and Paul Auster's Moon Palace." Pragmatism and Literary Studies. Ed. Winfried Fluck. Tübingen : Narr, 1999. 93-110.

Ruiter, Frans. "Postmodernism in the German- and Dutch-Speaking Countries." International Postmodernism : Theory and Literary Practice. Ed. Hans Bertens and Douwe Fokkema. Amsterdam : Benjamins, 1997. 359-73.

Schabert, Ina. "No Room of One's Own : Women's Studies in English Departments in Germany." PMLA 119.1 (2004) : 69-79.

Schiller, Georg. "Writing About Transcendence and Writing as Transcendence : Native American Literature from the 1960s to the 1990s in Dialogue with Pragmatism" The Sixties Revisited: Culture, Society, Politics. Ed. Jürgen Heideking, Jürgen Helbig, and Anke Ortlepp. Heidelberg : Winter, 2001. 341-55.

Schivelbusch, Wolfgang. Entfernte Verwandtschaft : Faschismus, Nationalsozialismus und New Deal, 1933-1939. München : Hanser, 2005.

Schleusener, Simon. "Deleuze und die American Studies." Amerikastudien / American Studies 49.2 (2004) : 219-40.

Schöpp, Joseph. Ausbruch aus der Mimesis. München : Fink, 1990.

Schulenberg, Ulf. "Wanting Lovers Rather than Knowers-Richard Rorty’s Neopragmatism." Amerikastudien / American Studies 48.4 (2003) : 577-608.

Showalter, Elaine. "Feminist Criticism in the Wilderness." The New Feminist Criticism : Essays on Women, Literature, Theory. Ed. Elaine Showalter. New York : Pantheon, 1985. 243-70. 
Sielke, Sabine, and Elisabeth Schäfer-Wünsche. "How German Is It? Projektionen des Deutschen in der amerikanischen Kultur." Deutschlandbilder im Spiegel anderer Nationen. Ed. Klaus Stierstorfer. Reinbek : Rowohlt, 2003. 155-91.

Sielke, Sabine. Fashioning the Female Subject : The Intertextual Networking of Dickinson, Moore and Rich. Ann Arbor : U of Michigan P, 1997.

---. "Science/Fiction : The Future of American Studies. European Perspectives." Science, Technology, and the Humanities in Recent American Fiction. Ed. Peter Freese and Charles B. Harris. Essen : Blaue Eule, 2003. 521-48.

---. “Why Gender Matters : Zur Bedeutung der gender studies für die Amerikastudien.” Gender Matters : Amerikastudien und Geschlechterforschung. Ed. Sabine Sielke. Berlin : John F. KennedyInstitut, 1997. 1-16.

Siemerling, Winfried. The New North American Studies : Culture, Writing, and the Politics of Re/ cognition. New York : Routledge, 2005.

Sklar, Robert. "American Studies and the Realities of America." American Quarterly 22 (1970) : 597-605.

Spiller, Robert E. "Value and Method in American Studies : The Literary versus the Social versus the Literary Approach." Jahrbuch für Amerikastudien 4 (1959) : 11-24.

Strunz, Gisela. American Studies oder Amerikanistik : Die deutsche Amerikawissenschaft und die Hoffnung auf Erneuerung der Hochschulen und der politischen Kultur nach 1945. Opladen : Leske, 1999.

Weimann, Robert. "Literaturwissenschaft und historisch-materialistische Theorie : Aktuelle Fragen der Entwicklung der Literaturtheorie und Methodologie in der Anglistik-Amerikanistik." Zeitschrift für Anglistik und Amerikanistik 28.1 (1980) : 12-31.

---. New Criticism und die Entwicklung bürgerlicher Literaturwissenschaft. Halle : Niemeyer, 1962.

---. "Westöstliche engagements : Eine bi(bli)ographische Reminiszenz." Amerikanistik in der DDR : Geschichte-Analyse-Zeitzeugenberichte. Ed. Rainer Schnoor. Berlin : trafo, 1999. 173-88.

Zapf, Hubert, ed. Amerikanische Literaturgeschichte. 2nd rev. ed. Stuttgart : Metzler, 2004.

Ziegler, Heide. "Directions in German American Studies : The Challenge of the New Historicism." America Seen from the Outside: Topics, Models, and Achievements of American Studies in the Federal Republic of Germany. Ed. Brigitte Georgi-Findlay and Heinz Ickstadt. Berlin : Freie Universität Berlin, 1990. 54-67.

Žižek, Slavoj. "Die Schuld des Blicks." Die Metastasen des Genießens : Sechs erotisch-politische Versuche. Ed. Peter Engelmann. Wien : Passagen, 1996. 191- 215.

\section{NOTES}

1.I thank Markus Fischer for excellent research assistance.

2.In this context, Robert Weimann's work would be particularly significant. See Weimann, New Criticism, "Literaturwissenschaft" "Westöstliche engagements"; cf. also Riese.

3.Günter Lenz has provided us with indispensable work on the development of American Studies and its theories and methods, to parts of which I make reference throughout this essay, though I cannot do justice to its overall scope. As a general rule my own perspective is limited to theoretical discussions within German American 
Studies, even if this work, as I am well aware, evolves in dialogue with work done in the U.S. On the history of American Studies/Amerikanistik in Germany see Strunz and Haas. 4.Günter Lenz, in particular, has argued, that "[o]nly if the history of American Studies is taken seriously in its theoretical implications, and not just used as a negative foil for suggesting a new program, can their 'crisis' be understood and become consequential for a 'philosophy' of American Studies in the future." In 1982 he suggested "that a 'theory' or 'philosophy' of American Studies will have to grow out of a systematic historical reconstruction of the development and the crisis of the American Studies movement" ("American Studies-Beyond the Crisis?" 63, 82).

5.This essay does not make any claims at comprehensiveness; in fact, for the sake of argument, I fear it turned out quite partial. I do regret, though, the omission of many German contributions to theorizing American Studies, I apologize for my tunnel vision, and beg for my readers' mercy.

6.See, especially, Ickstadt, "American Studies"; Lenz, "Toward a Dialogics,"

"Transnational American Studies"; Hornung, "Transnational American Studies," which was the reply to Fishkin. See also recent projects which attempt to "foster," as the journal Atlantic Studies: Literary, Cultural, and Historical Perspectives does, "a transcultural dialogue between the two hemispheres and, specifically, the nations of Europe, the Americas, and Africa" (cf. journal flyer).

7.See Huyssen as well as Brook, both of whom employ a conception of distinct, yet interrelated histories and subjectivities in place of more traditional linear, teleological conceptions of (cultural) history. Throughout, Lenz's essays emphasize the interdependence of multiple critical positions or explicitly acknowledge the synchronicity of non-synchronic theoretical approaches; see, for instance, Lenz, "Reconstructing" 32. Similarly, this conception affected critical practice: In his study of postmodern poetry Ulfried Reichardt differentiates between the very particular, yet synchronic poetics of John Ashbery, A.R. Ammons, Denise Levertov, and Adrienne Rich; see Innenansichten. Hartwig Isernhagen depicts the New English Literatures as characterized by a "Gleichzeitigkeit des Ungleichzeitigen" (162-63).

8.This question in fact motivated the founding of the Post-Graduate Forum which, in 1989, was primarily conceived of as a network of doctoral candidates in American Studies and a forum for debates on what we then considered 'new' theories. Cf. also the first publication of the Post-Graduate Forum (Irmscher and Sielke).

9.This line of my argument is highly indebted to the research pursued by the network "The Futures of (European) American Studies," funded by the Deutsche

Forschungsgemeinschaft and coordinated by Elisabeth Schäfer-Wünsche. I will come back to this point at the end of my essay.

10.All translations from the German are mine. The German reads: "Theorien sind Ordnungs- und Hierarchisierungsversuche von kulturellem Material, die immer da notwendig werden, wenn der Status und Stellenwert eines Gegenstandsbereichs unklar oder umstritten ist."

11.This goes as much for Adorno, as for $O$. Hansen, and Lenz "American StudiesWissenschaftskritik."

12.I make reference here to Marx's contribution to the conference on "Theories of American Culture" at the John F. Kennedy-Institut in May 2002, published as "On Recovering."

13.The significance of American Studies/Amerikanistik for the development of this dialogue should not be underestimated. In fact, as Gassert's study Amerika im Dritten 
Reich emphasizes, American Studies emerged within and against the climate of a highly ambivalent perception of the United States (116-36). Schivelbusch's recent study Entfernte Verwandtschaft, which perceptively discloses parallels between Italian fascism, German national socialism, and the American New Deal, may throw new light on these ambivalent interdependencies.

14.Fluck, in particular, has employed the term Americanization to delineate the impact of American perspectives on central terms of literary and cultural studies. Cf. his essays “The 'Americanization," and "Die 'Amerikanisierung' der Geschichte"; see also Isernhagen, "Postmodern (Dis)continuities."

15.See, in particular, O. Hansen, and Lenz, "American Studies-Wissenschaftskritik." In 1973 the annual conference of the German Association for American Studies in Tutzing was dedicated to "American Studies als wissenschaftstheoretisches Problem."

16.See Milich. O. Hansen, in his essay "American Studies," adopts Kuhn's terminology to distinguish five paradigms that, he argues, structured the debate about theories of American Studies at the time.

17.When I talk about 'early American Studies' in this essay, I am referring to the early history of the field, not to early American cultural history.

18.The success of Paul Nolte's argument on mass culture may serve as an example here (Generation Reform).

19.This is due to the fact that, as Hans-Jürgen Grabbe emphasizes, American Studies was established primarily within established disciplines and first and foremost in English departments, which in turn needs to be registered as a success for literary studies (172).

20.See, for instance, Freese and Harris; Berressem; and Mayer. Work on ecocriticism, pursued by Christa Grewe-Volpp and Sylvia Mayer, for instance, also foregrounds that American Studies may profit much from engaging the natural sciences and their cultural history.

21.The work of Homi Bhabha, for instance, has gained a lot of mileage from recontextualizing the term 'mimicry' without giving feminist critique, far and foremost Luce Irigaray, much credit for it.

22.On the issue see Isernhagen, "American Studies." Isernhagen suggests that regarding "American Literature as the first of the New Literatures in English" opens new perspectives on the question of what "American" actually means (158).

23.Cf. Christoph Ribbat's essay in this volume.

24.Paul Lauter has shown that many literary texts, authored by female and African American writers and central to 1920 s and 30s American cultures, were deleted from the canon of American literature in the 1940s and 50s (435-63). Adorno's argument on jazz is legend, of course.

25.The complicated interdependencies of German and American racial ideologies and politics have been addressed, for instance, in the debates on the Americanization of the Holocaust. Cf. Rohr, "Playing Nazis," as well as work by Heike Paul and Hilke

Kuhlmann, among others. See also Isernhagen, "Roles of Native American Texts"; Sielke and Schäfer-Wünsche.

26.In fact the diversity of perspectives within African American Studies (cf. the work of Berndt Ostendorf, Maria Diedrich, Friederike Hajek, Werner Sollors, Elisabeth SchäferWünsche, Sieglinde Lemke, among many others) and Native American Studies (cf. Gerhard Hoffmann, Hartmut Lutz, Maria Moss, Thomas Claviez, and Georg Schiller, to mention only a few names) attests to the centrality of these two fields within German 
American Studies (see Lutz). Likewise, it is interesting to note how early and how insistently, under the given economic constraints, African American and Native American texts were translated into German in the GDR (cf. van der Heyden). 27.This tendency also functioned vice versa, it seems: In 1984 Lenz notes a decrease of interest in an inter- or multidisciplinary American Studies and, if compared with the discussion in the United States, what he considers a "Theoriedefizit" ("Probleme einer Didaktik" 23).

28. Reference was, first and foremost, to Robert Sklar whose influential essay "American Studies and the Realities of America" (1970) argued that "American Studies, as an intellectual discipline, is in crisis," in fact "has always been in crisis" (qtd. in Lenz, "American Studies-Beyond the Crisis?" 55).

29.This tendency holds true in the American university system as well; see Newfield. 30.According to Hansen the capacities of American Studies to synthesize different scholarly approaches showed, for instance, in their ability to redirect the humanities from analyses of the past to a consideration of contemporary literature and culture, a focus that was associated more strongly with the sciences (whereas the social sciences supposedly took a middle position).

31.This is still the case, for instance, in parts of Eastern Europe, Asia, and North Africa. 32.The definition of "radical American Studies" has changed and shifted, of course. In 1973 Olaf Hansen refers to the politicization of American Studies in the early 1970s, which was accompanied by a growing emphasis on the social sciences and effected by the work of critics such as Sklar and Gene Wise, critics who called the ideologies of the early American Studies into question and insisted that the field take account of the material social realities of American culture. From this perspective the centrality of literary studies was highly contested. "[T]he larger the difference between the promises of culture and the social realities," Hansen writes, "the more problematic the occupation with literature becomes" (168). For a history of "radical American Studies" from the 1930s to the 1960s, see Lenz, "American Studies and the Radical Tradition." 33. Contextualism is a term that Fluck derives from Murray Krieger, cf. Krieger. 34.I make reference here to the project proposal of the DFG-Network "The Futures of (European) American Studies."

35.See, for example, Miller; and Hof, "Writing Women."

36.Significant in this context is, for instance, the impact of poststructuralist theory on the study of autobiography. See Hornung, "American Autobiographies."

37.For a more detailed analysis of the significance of conceptions of gender for American Studies, see Sielke, "Why Gender Matters"; see also Koenen; Reichardt and Sielke. As opposed to U.S. academia, German universities and their English departments have not really lived up to the challenge of feminist and gender theories, cf. Schabert; and Hark.

38.It is thanks to the work of Evelyne Keitel, Elisabeth Bronfen, Gisela Ecker, Renate Hof, Sigrid Weigel, among many others, that the insights of Freudian and Lacanian psychoanalysis, French poststructuralism, and the continuous redefinition of gender based on this work significantly enlarged our perspectives on the work that (American) culture performs and made us aware of American misreadings of well-travelled continental theories. See, in particular, Hof, "Einleitung"; and Keitel. For a historicization of French feminist theory see also Sielke, Fashioning. 
39.See especially the work of Heinz Ickstadt, Peter Freese, Gerhard Hoffmann, Alfred Hornung, Hartmut Isernhagen, Joseph Schöpp, Hanjo Berressem, Martin Klepper, among many others. Cf. Neubauer.

40.This is due in part to the fact that New Criticism capitalized on poetry, in part to the cultural function of early American Studies, which aimed at establishing a respectable canon of American literature. Thus, the myth and symbol school turned to romance and transcendentalism to coin the misnomer American renaissance. Poststructuralist approaches reengaged American romanticism and (post-)modernist texts while the New Historicism found in sentimentalist, realist and naturalist texts its most promising target. Each of these interactions redefine the relation between theory and cultural practice.

41.In Germany, this revision evolved the highly useful Amerikanische Literaturgeschichte, edited by Hubert Zapf.

42. Theories of postcoloniality, apart from New Historicism, still remain marginal to the field of American Studies, which is partly due to the fact that postcolonial criticism employs the, albeit contested, distinction between settler and non-settler colonies. There are, of course, many exceptions to this tendency, among them Ruth Mayer's study Artificial Africas. One may perhaps also figure in here attempts to 'make use' of Deleuze for American Studies, delineated by Schleusener. Against ideologically motivated readings which, according to Deleuze, cannot account for the affects and intensities of literary texts, Deleuze abolishes, as Schleusener argues, the fixity called America and offers the conception of 'minor literatures' to be contextualized within postcolonial critiques.

43. Accordingly, issues of globalization are central to current American Studies; cf. Bach, Bröck, and Schulenberg.

44.I make reference here to Siemerling's study, which includes material from the United States and Canada, yet does not extend its project of retheorizing the field to Mexico.

45.Let me emphasize that I am not concerned with the development of the field of American history here, but with the changing definition of the historical as it impacted on the study of American literature and culture.

46.See Reichardt, "Poststrukturalismus"; and Hebel. In New Historicism, Moritz Baßler explicitly aims at making German historians familiar with new historical perspectives and provides a German audience with paradigmatic texts by Stephen Greenblatt, Louis Montrose, and Svetlana Alpers, among others (see "Einleitung"). The editor includes Fluck's essay "Die 'Amerikanisierung' der Geschichte" and acknowledges that this 'method' has first been productively employed in Germany in the context of "Amerikanistik" (24).

47.In 1983 the annual conference of the German Association for American Studies in Kiel focused on "Amerikastudien als Kulturwissenschaft: Modell- und Paradigmenwechsel."

48. There are, of course, many historians who resist this redefinition as well as historians who reclaim genres or texts as historiographic, which recent theory had claimed to be fictional; see, for instance, Lehmkuhl.

49.Fluck himself was highly instrumental in making German American Studies familiar with the 'new historicism' in the 1980s and 1990s; see also Hebel; and Baßler, New Historicism. 
50.For a critical discussion of Greenblatt's sense of "circulation of social energies," see Haselstein.

51.To my mind Mackenthun's essay seems to exemplify a general tendency within German American Studies, on the one hand, to embrace new historical perspectives and thereby revitalize, for instance, the study of the colonial period and matters of colonization while, on the other, resisting part of its poststructuralist foundations. 52.The term synthesis looms large, for instance, in the essay collection Reconstructing, ed. Lenz, Keil and Bröck-Sallah. Part of the volume is dedicated to 'the problem of' or rather "the need for synthesis," as Thomas Bender puts it in his much-discussed essay first published in the Journal of American History (1986) and reprinted in Lenz, Keil and Bröck-Sallah.

53.In turn philosophers like Richard Rorty and Martha Nussbaum engage literary practice for its ethical potential, a potential which is as new and promising to them as it is familiar fare to scholars of literary theory. In fact, Nussbaum employs a highly dated conception of literature, which puts a clear limit to the scope of her argument; see, for instance, Nussbaum, Love's Knowledge and Poetic Justice.

54.Fluck discusses the collections The Revival of Pragmatism, ed. Dickstein; Pragmatism, ed. Goodman; and Pragmatism, ed. Menand, as examplary for the revival of pragmatism, yet "remain[ing] surprisingly weak and unfocused, in the area of art, literature, and culture" (x). In German American Studies, Herwig Friedl has consistently employed pragmatist philosophy in order to reassess crucial moments of American culture as well as the scope of American pragmatist thought without, however, necessarily positioning his argument within the debates around theories of American Studies. See, for instance, "Art and Culture," "Thinking America," "Global Aspects," and "Thinking in Search of a Language." Rorty's neopragmatism has been explored by Reinhard and Schulenberg, for instance, in "Wanting Lovers."

55.The German reads: "Primat des Erkenntnisprozesses über den Gegenstandsbereich." 56.Fluck sees this "politics of self-empowerment" as the main goal of the cultural radicalism he finds characteristic for the current state of the humanities in the United States; see also Fluck, "The Role of the Reader."

57.On the subject of mimesis and its 'beyonds,' see, for instance, Schöpp; and Ickstadt, Der amerikanische Roman.

58.This goes for Gender Trouble as well as for Butler's essay "Performative Acts" which lays the groundwork for her later arguments.

59.The subject himself or herself is, we can read in the German original, "Schauplatz dieser Ambivalenz" in which he or she evolves "sowohl als Effekt einer vorgängigen Macht wie als Möglichkeitsbedingung für eine radikal bedingte Form der Handlungsfähigkeit" (Die Psyche der Macht 19).

60.This is the context for a revival of Emerson's poet who reappears in Rorty's "strong poet."

61.The German text reads: "mehr eine ideengeschichtliche Konstruktion als ein konkretes, in sozialen Zusammenhängen motiviertes Individuum."

62.See, for instance, the passage I quoted at the beginning of this subchapter. 63.Or as Fluck puts it in 1987: "[...] auch wo eine Beschäftigung mit dem Gegenstand nicht explizit von einem systematischen Begründungszusammenhang ausgeht, ist sie doch unvermeidlicherweise eingebunden in ein System theoretischer Annahmen, das die jeweilige Interpretationspraxis gewollt oder ungewollt, bewußt oder unbewußt leitet und sich daher auch aus dieser rekonstruieren läßt" (Theorien 5). 
64. Needless to say any list of references in this context cannot be but incomplete and partial. Cf., for instance, research that evolved in the vicinity of the Visual Culture Network (e.g. work by Christoph Decker and Ernst-Peter Schneck, among others); writing on popular culture by Karin Esders, Ruth Mayer, Christoph Ribbat, and Elisabeth Schäfer-Wünsche; and work on hyperculture edited by Martin Klepper, Mayer, and Schneck.

65.I quote from the network's initial project proposal.

66. Accordingly the 2006 annual conference of the German Association for American Studies in Göttingen explores "American Studies as Media Studies."

67.I make reference here to the summer school "Outside American Studies," organized by Donald Pease and Robyn Wiegman at Dartmouth College.

\section{RÉSUMÉS}

Partly due to the transdisciplinary agenda of the field, the development of American Studies has been accompanied by intensive debates about methods and theories. This essay relates anecessarily reductive-narrative about how, throughout its history, German American Studies has intervened into and contributed to these debates; and how, with the emergence of parameters and politics of difference, on the one hand, and poststructuralist thought and notions of différance, on the other, the early debate on methods of American Studies transformed into discussions of theories of American literature, culture, history etc. In the light of what I perceive as the current division within German American Studies-a division between work that refocuses the theoretical discussion on literary studies and questions of aesthetics and analyses that engage other cultural practices and media by way of explicit theoretical perspectives, yet not necessarily in the frame of an American Studies agenda-my argument suggests that we take a more dialectical approach to the plurality of theories American Studies engages. While such an approach can no longer aim at syntheses and needs to allow for incoherencies and contradictions, it seems indispensable if we aim at futures for American Studies. ${ }^{1}$

\section{INDEX}

Keywords : Literature, history, interdisciplinarity, pragmatism, culture, transdisciplinarity, poststructuralism, aesthetics, pluralism 